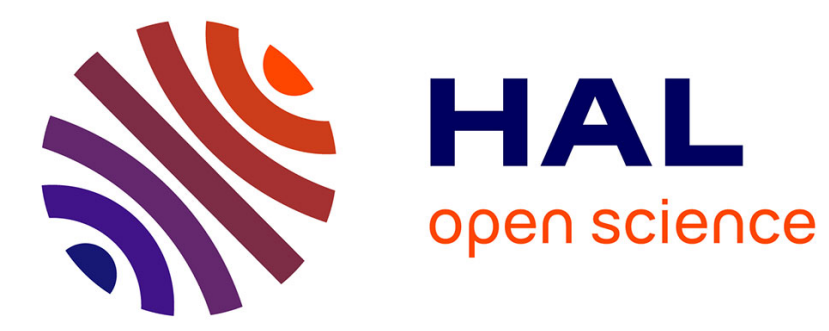

\title{
Source rocks in foreland basins: a preferential context for the development of natural hydraulic fractures
}

Alain Zanella, Peter R Cobbold, Nuno Rodrigues, H Loseth, Marc Jolivet, F Gouttefangeas, D Chew

\section{- To cite this version:}

Alain Zanella, Peter R Cobbold, Nuno Rodrigues, H Loseth, Marc Jolivet, et al.. Source rocks in foreland basins: a preferential context for the development of natural hydraulic fractures. AAPG Bulletin, 2021, 105 (4), pp.647-668. 10.1306/08122018162 . insu-03010282

\section{HAL Id: insu-03010282}

\section{https://hal-insu.archives-ouvertes.fr/insu-03010282}

Submitted on 17 Nov 2020

HAL is a multi-disciplinary open access archive for the deposit and dissemination of scientific research documents, whether they are published or not. The documents may come from teaching and research institutions in France or abroad, or from public or private research centers.
L'archive ouverte pluridisciplinaire HAL, est destinée au dépôt et à la diffusion de documents scientifiques de niveau recherche, publiés ou non, émanant des établissements d'enseignement et de recherche français ou étrangers, des laboratoires publics ou privés. 


\section{(2.)AAPG BULLETIN}

Source rocks in foreland basins: a preferential context for the development of natural hydraulic fractures.

A. Zanella, P.R. Cobbold, N. Rodrigues, H. Loseth, M. Jolivet, F. Gouttefangeas, and D. Chew

AAPG Bulletin published online 28 August 2020

doi: 10.1306/08122018162

Disclaimer: The AAPG Bulletin Ahead of Print program provides readers with the earliest possible access to articles that have been peer-reviewed and accepted for publication. These articles have not been copyedited and are posted "as is," and do not reflect AAPG editorial changes. Once the accepted manuscript appears in the Ahead of Print area, it will be prepared for print and online publication, which includes copyediting, typesetting, proofreading, and author review. This process will likely lead to differences between the accepted manuscript and the final, printed version. Manuscripts will remain in the Ahead of Print area until the final, typeset articles are printed. Supplemental material intended, and accepted, for publication is not posted until publication of the final, typeset article.

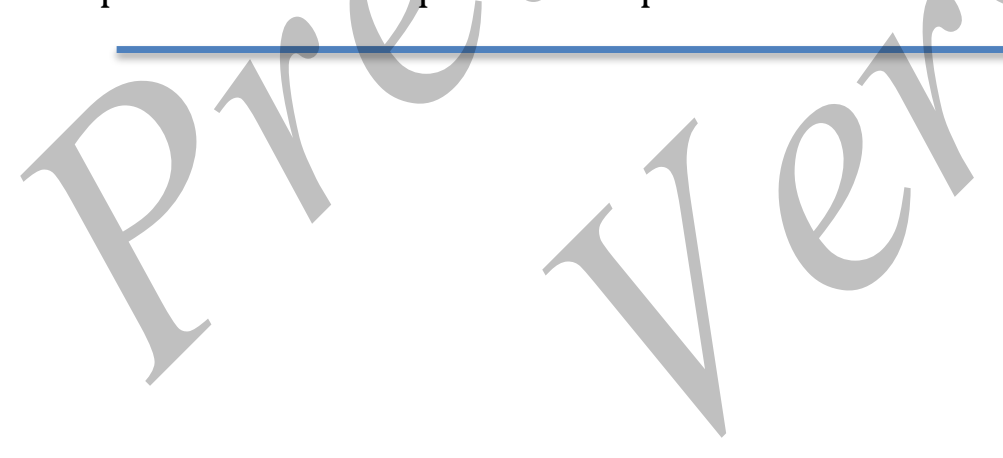

Cite as: Zanella, A., P.R. Cobbold, N. Rodrigues, H. Loseth, M. Jolivet, F. Gouttefangeas, and D. Chew, Source rocks in foreland basins: a preferential context for the development of natural hydraulic fractures., (in press; preliminary version published online Ahead of Print 28 August 2020): AAPG Bulletin, doi: 10.1306/08122018162.

Copyright (C) Preliminary Ahead of Print version 2020 by The American Association of Petroleum Geologists 


\section{Source rocks in foreland basins: a preferential context for the 2 development of natural hydraulic fractures.}

3

4

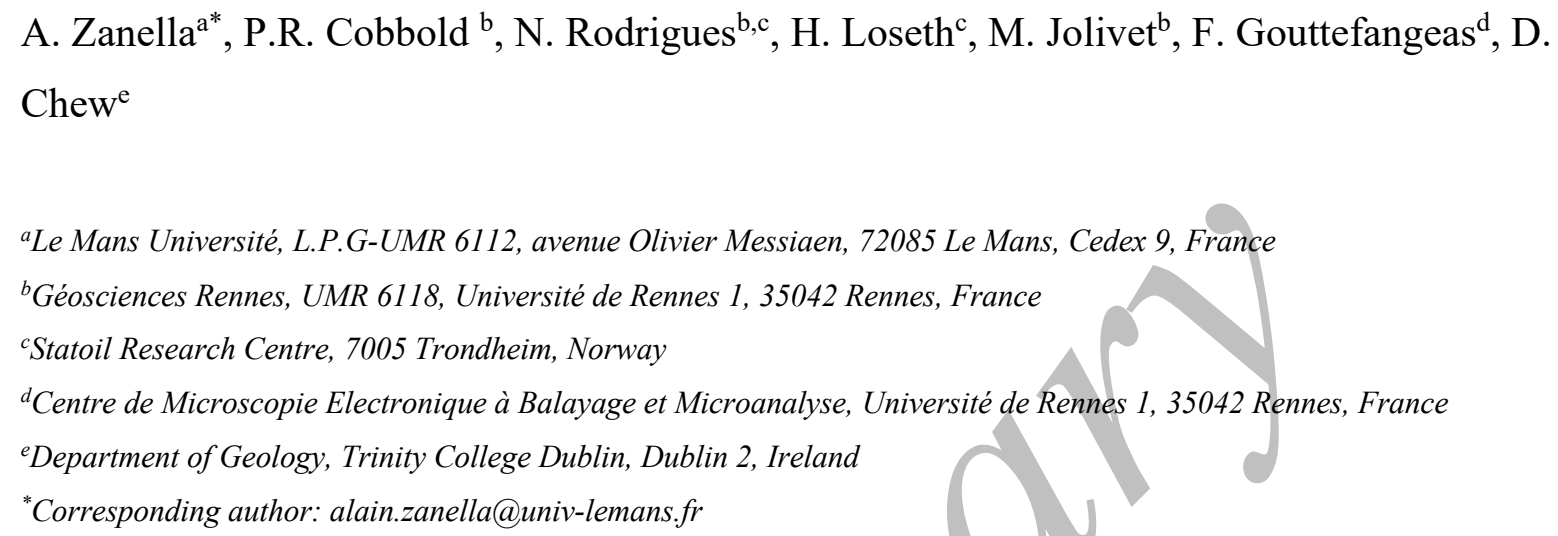

\section{KEYWORDS}

beef veins; natural hydraulic fractures; petroleum source rocks; fluid overpressure; foreland basins

\section{ABSTRACT}

Bedding-parallel veins of fibrous calcite (also called BPV or 'beef') occur in many sedimentary basins, especially those containing low-permeability strata with organic source material for petroleum. The formation of such veins is often linked with fluid overpressure in these source rocks. In this review, we demonstrate that beef veins are most commonly present in foreland basins worldwide or in basins that recorded a compressive tectonic period. The formation of beef veins is related to two main phases: (1) the initiation of bedding-parallel fracture and (2) the infilling of the fracture.

Previous structural studies have shown that formation of beef veins occurred during a period of compressive stress activity. This is especially the case for the Wessex Basin (UK) and the Neuquén Basin (Argentina). Here we provide more observations for other basins: the Cordillera Oriental (Colombia), the Paris Basin (France), the northern Pyrenees (France), the Uinta Basin (US), the Tian Shan Mountains (central Asia) and the Appalachian Mountains (US). In the Paris Basin, beef vein formation is dated at $155 \mathrm{Ma}(\mathrm{U} / \mathrm{Pb}$ calcite method) and is coeval with the compressional deformation in the eastern part of the basin.

Because of the timing of generation for such veins and even if the theory and the experiments of 3 fracturing demonstrate that bedding-parallel fractures can be generated only with a distributed fluid 4 overpressure, the formation of beef veins seems to be a consequence of both fluid overpressures and a 5 compressional tectonic stress. 
Many of the major mountain ranges around the world have resulted from recent horizontal shortening and vertical thickening (Figure 1). Others have resulted from rifting, strike-slip faulting or uplift associated with magmatism. In contrast, most older mountain ranges have tended to disappear by active erosion of their sharp topographic profiles. For recent shortening and thickening, the main causes are (1) subduction beneath active continental margins, especially in the Atlantic and Pacific oceans, or (2) continental collision, for example between Europe and Africa or central Asia and India (Figure 1). In such tectonic settings, there has been progressive development of adjacent foreland basin systems as a result of thrusting and local sedimentation and in many cases, they contain petroleum systems.

Because they are commonly hydrocarbon-bearing, foreland basins are major targets for the study of source rocks and reservoirs. In the last twenty years, organic-rich source rocks have been extensively studied because of their hydrocarbon potential. Within these sedimentary units, many fractures occur and some of them can affect the permeability as well as the cap capability of the source rocks. This is especially the case for the natural hydraulic fractures, such as bedding-parallel veins (also called BPV or 'beef'). The first examples of beef to be described were likely those in the Wessex Basin of Southern England (Buckland \& De la Beche, 1835). The veins were easily observable along coastal cliffs and provided useful material for building walls and roads. More generally, beddingparallel veins are common worldwide in sedimentary basins, especially those containing hydrocarbons, indicating that the host rock has reached maturity (Cobbold et al., 2013; Gale et al., 2014). The formation of such veins is often linked to fluid overpressure during hydrocarbon generation (Rodrigues et al., 2009; Zanella et al., 2015a). Beef veins therefore consist of natural hydraulic fractures, infilled by a fibrous mineral, such as calcite, gypsum or quartz (Cobbold et al. 2013). Other mechanisms are also involved, but seem to be more minor, such as, for example, the force of crystallization (e.g. Taber, 1916; Means \& Li, 2001; Gratier et al., 2012). Recent studies have shown that many bedding-parallel veins formed during horizontal shortening, as in the Wessex Basin, southern England, (Zanella et al., 2015b), in the Bristol Channel Basin, England and Wales, (Meng et al., 2017), or in the Neuquén Basin of western Argentina (Rodrigues et al., 2009; Ukar et al., 2017; Ukar et al. 2018).

This paper presents a worldwide review of bedding-parallel veins (natural hydraulic fractures) within foreland basins and discusses the development of such natural hydraulic fracturing processes within this particular tectonic basin setting. We also present new observations and data to complete those of previous studies, particularly with respect to four localities: (1) the Northern Pyrenees, France; (2) the Uinta Basin, USA; (3) the Tian Shan Basin, China and (4) the Appalachian Basin, USA. 


\section{Formation of beef veins}

The simplest calcite beef veins, which form in tectonically quiescent basins, are typically beddingparallel (horizontal), of regular thickness and contain calcite fibers, which have formed almost vertically and antitaxially, separating the two boundaries of the fracture. The best evidence for epitaxial separation comes from the presence of flattened fossils (for example, ammonites), which remain in the central part of the vein, while counterparts of them are visible at the two outer boundaries, but displaced along the directions of the calcite fibers, which may be somewhat oblique (Rodrigues et al., 2009). Other forms of calcite beef are cone-in-cone structures, which likely form as a result of shear faulting during epitaxial growth of the calcite veins (e.g. Cobbold et al. 2013).

Two successive phases characterize the formation of a beef vein: (1) the initiation of the fracture and (2) the opening of the fracture. For the initiation of the fracture, the model can explain the generation of horizontal hydraulic fractures without external tectonic stresses (e.g. compressive stress) (Cobbold et al. 2007, Mourgues \& Cobbold, 2003). However, much of our knowledge of the mechanisms involved in such processes come from experimental models developed during the early $21^{\text {st }}$ century. In the early iterations of these experimental models, the pore fluids were injected from the outside, at measured rates and pressures (Cobbold \& Castro, 1999; Mourgues \& Cobbold, 2003). Thus, it became clear that vertical gradients of overpressure counteract the weight of the granular material. When noncohesive materials were also compressed horizontally, the pore fluid gradient facilitated detachments for thrust faults and caused these to become more nearly horizontal (Cobbold et al., 2001). When the material was cohesive, the vertical pressure gradient generated horizontal tensile fractures, which opened progressively (Cobbold \& Rodrigues, 2007). Moreover, when the models were also compressed horizontally, the resulting stresses facilitated the formation of horizontal tensile fractures. Because the early experimental models simulated the origin of the fluid overpressure as an injector-type system, they were not adapted for the study of the origin and mechanisms involved in the development of such fluid overpressures.

Thus, to be able to study the origin of fluid overpressures and the parameters involved in the

103 process of natural hydraulic fracturing within source rocks, later experiments have used transition

104 phases (solid to liquid), to produce a fluid within a closed experimental setup. From solid organic particles (such as beeswax microspheres), models were able to generate a fluid by chemical compaction-like mechanisms, which occur during burial of organic-rich source rock (Fig. 2;

107 Lemrabott \& Cobbold, 2010; Zanella et al., 2014a). In such models, the wax was able to melt, on

108 heating the model from below. The resulting decrease in underlying support allowed solid particles to move downwards, causing compaction of the underlying framework and an increase in pore fluid 
pressure, by a mechanism of load transfer (Zanella et al. 2014a). In other models, which were saturated with water but not subject to horizontal shortening (Figure 2), the overpressure developed soon after

112 the temperature had reached the melting point of beeswax, at the base of the model. This overpressure

113 became great enough to cause horizontal hydraulic fracturing of the wax-rich layer. Molten wax then

114 migrated vertically and horizontally through the pore space and filled the opening generated by

115 hydraulic fractures. In similar models, which were also subject to horizontal shortening, the hydraulic

116 fractures developed more strongly, becoming wider and longer. Furthermore, many of the fractures

117 varied laterally in thickness and orientation, as a result of local folding and thrust faulting.

For the filling of the natural hydraulic fractures, beef veins appear to have incrementally grown

121 fibers appear to have grown incrementally during the displacement of the edges of the veins by a

122 crack-seal mechanism (Ramsay, 1980) or more continuously (Taber 1918; Durney \& Ramsey, 1973;

123 Means \& Li, 2001). The mechanisms involved in the formation of beef veins are complex and several

124 of them have been postulated by previous authors. The opening of the vein implies a key mechanism

125 already describe by several authors: the force of crystallization (e.g. Baker et al., 2006; Bons, 2001;

126 Bons et al., 2012; Keulen et al., 2001; Mean \& Li, 2001). Indeed, several experiments have

127 demonstrated the great importance of the force of crystallization in the beef vein opening (Bons \&

128 Jessel, 1997; Hilgers et al., 2001; Nollet et al., 2005, 2009) Thus, the tectonic stress, the pore fluid

129 pressure (fluid overpressures) and the force of crystallization appear to be the major mechanisms (e.g.

130 Sibson, 2003; Shearman et al., 1972; Stoneley, 1983; Taber, 1916; Gratier et al., 2012).

In many basins worldwide, the formation of beef veins seems to be linked to the generation of hydrocarbons, as showing by scanning electron microscopy for calcite beef of the Wessex Basin

134 (Zanella et al., 2015b), the Neuquén Basin (Rodrigues et al., 2009; Ukar et al. 2017, 2018), the

135 Magellan Basin (Zanella et al., 2014b) and the Paris Basin. All of these examples show that beef veins

136 contain inclusions of organic matter (liquid, solid or both) within or next to the calcite crystals,

137 indicating that the organic matter was diffusing, while the calcite crystals were growing. Other

138 examples of calcite beef, e.g. in the Lourdes area, the Uinta Basin or the Appalachians, may either

139 include or be adjacent to veins of organic material. Investigating the relationship between the organic

140 matter and the hydraulic fracturing, Zanella et al. (2014a) showed with their experiments that the

141 maturity degree is a key parameter to explain the increase of pore fluid pressure within source rocks

142 and that a horizontal compressive stress can favor the development of horizontal hydraulic fractures. 
A global topographic map (Figure 1) illustrates the occurrence of significant present-day

150

151

152

153

154

155

156

157

158

159

160

161

162

163

164

165

166

167

168

169

170

171

172

173

174

175

176

177

178

179

180

181

182 mountain ranges, especially along continental margins such as the Andes or within zones of continental collision (such as central Asia or the Alps). Many recent foreland basins have formed next to these current mountain ranges. Additional evidence for compressional reactivation of such mountains comes from stress maps on a global scale, which show directions of horizontal compressional stress (e.g. Heidbach et al., 2009). Although many such mountain ranges have formed recently and expose Mesozoic or younger rocks, others expose older rocks (Paleozoic or even Precambrian). In many cases, however, older mountain belts have been subject to recent localized reactivation, such as the Appalachian Mountains in the eastern US and Canada, but also parts of the mountains of Scotland, Norway, Brazil, northern Africa or Australia. Indeed, such reactivation explains why the mountains still exist today, despite relatively active erosion.

Foreland basins (such as those next to the Andes) tend to have relatively low and flat upper surfaces, but deep basements, which have subsided, as a result of (1) the weight of nearby mountains, (2) the propagation of outward-verging thrust faults, (3) the local accumulation of sediments derived from erosion of the mountains, (4) the accumulation of evaporites or limestones within local depressions and (5) the accumulation of volcanic and plutonic rocks propagated out from the mountain belt, especially in subduction zone settings.

Petroleum source rocks (commonly of Mesozoic age, but also of Paleozoic age) often have formed within many of these foreland basins, in part because the surface depressions yield sufficient accomodation space, but also because of suitable climatic and environmental conditions. Progressive subsidence of foreland basins leads to heating and maturation of source rocks at depth. Fluid overpressure tends to be common within such source rocks, as a result of the heating, maturation, increases in volume and chemical compaction (under the weight of the overlying rock column and the effect of horizontal tectonic compression). Such heating is mainly associated with burial but may also be due to magmatic intrusions, especially in subduction zone systems (Zanella et al. 2015a).

Finally, thrust detachments are common in foreland basins, especially within overpressured source rocks, where seepage forces counteract the weight of gravity and sedimentary strata providing an anisotropic mechanical response (Cobbold et al., 2001).

\subsection{Calcite beef within foreland basins (Mesozoic host rocks)}

Calcite beef is common within petroleum source rocks, especially those which have reached maturity (Table. 1). In the last few years, several authors have described examples of beef within foreland basins, especially within Mesozoic rocks of the Wessex Basin (UK), the Neuquén Basin 
183 (Argentina), the Magellan Basin (Chile and Argentina) and the Paris Basin (France). Other examples

184 have been described worldwide (e.g. Cobbold et al., 2013; Gale et al. 2014), although not necessarily

185 in such detail.

186 Where a basin has been subject to compressional tectonics, it may also contain synchronous

187 calcite beef. Typically, the veins will then be variable in thickness and orientation (Figs. 3, 4 and 5). A

188 vein may vary in thickness across small amplitude folds becoming thicker within synclines and thinner

189 over anticlines. Other variations in thickness may occur across reverse faults (see the examples from

190 the Wessex Basin; Figure 3). In the Magellan Basin, Zanella et al. (2014b) show that beef vein

191 occurrences are more numerous closed to main thrust faults. Finally, some veins may have formed

192 obliquely to bedding, (i.e. nearly horizontally) after the bedding has rotated, as a result of

193 compressional deformation. These structures are similar to some of those described from the

194 experimental modeling with fluid overpressures (Zanella et al., 2014a).

The Wessex Basin covers much of southern England (Figure 3A) and consists of Mesozoic and Cenozoic rocks that young in general towards the east, but is subject to folding and faulting, especially near the southern basin margin (Wight-Bray and Purbeck faults). A north-south section across the Purbeck fault (Figure 3A) and its restoration, published by Underhill \& Stoneley (1998), show that much of the slip has been of Late Cretaceous to Cenozoic age. The Wessex Basin also has several oilfields, which produce hydrocarbons from Jurassic source rocks (Underhill \& Stoneley, 1998).

Within the Liassic source rocks, calcite beef are common and have drawn attention for many years from geologists (e.g. Lang et al., 1923; Richardson, 1923; Buckland \& De la Beche, 1835;

206 Marshall, 1982), who at first attributed them to early diagenesis of the sediments. However, later work 207 revealed epitaxial growth of calcite fibers (e.g. Cobbold \& Rodrigues, 2007), after splitting of the rock.

On studying other calcite veins in the Purbeck Formation (latest Jurassic or Early Cretaceous) at 210 Lulworth Cove (above the Purbeck fault), Zanella et al. (2015b) discovered that many of them are 211 localized very closed to thrust faults (Figure 3). These veins show sigmoidal fibers (Fig. 3B \& C) as

212 well as variations in thickness around folds (Figure 3D). Such observations argue for a vein

213 development synchronous with a horizontal shortening period. Indeed, recent uranium-lead dating of

214 calcite (Chew et al., work in progress) has produced Albian ages (about $107 \mathrm{Ma}$ ) for such

215 compressional beef veins, both at Lulworth Cove and also at Charmouth (in the Shales-with-Beef

216 Formation of Liassic age). Thus, the beef veins in the Wessex Basin formed during the onset of

217 inversion tectonics. 
The Neuquén Basin covers an area of western Argentina, in the Andean foreland (Figure 4A). Its western margin is in the sub-Andes and it contains many north-northwest-trending folds. An eroded anticline exposes large areas of the Vaca Muerta Formation (Figure 4A), which is an Upper Jurassic organic-rich shale and a world-class source rock for oil. A geological section (Figure 4B, after Vera et al., 2014), through the city of Chos Malal (eastern side of the cross-section on Figure 4B), illustrates uplifted blocks of Palaeozoic basement, as well as thrust faults, many of which have detached near the base of the Vaca Muerta Formation.

Also, in the Vaca Muerta Formation are many examples of calcite beef. Although some of these veins are as much as $30 \mathrm{~cm}$ thick and are laterally continuous over distances of hundreds of meters (e.g. Cobbold et al., 2013, fig. 3A; Gale et al., 2014), others show local variations in thickness across minor folds and reverse faults (Figure 4A), indicating that they formed during horizontal compression and shortening. By analyses of the domal structures from beef veins, Ukar et al. (2017) concluded that beef veins, in the area of Loncopué, developed during the Late Cretaceous. This conclusion is consistent with Rodrigues (2008) and Weger et al. (2018), which concluded by isotopes analysis that beef veins growth occurred at depth related to high temperatures $\left(120^{\circ} \mathrm{C}\right.$ to $\left.185^{\circ} \mathrm{C}\right)$. Beef veins also occur elsewhere in the Neuquén Province (Cobbold et al., 2013) within shales of the Los Molles Formation (Lower Jurassic) or Agrio Formation (Lower Cretaceous). Finally, beef veins also occur in the Vaca Muerta Formation further north in Mendoza Province (Zanella et al., 2015a).

In summary, there is good evidence in the Neuquén Basin for recent overpressure, thrust detachments and multiple veins of compressional calcite beef, all within source-rock shale. Much of the heating was probably related to foreland subsidence, but some may have come from magmatic intrusions, which are abundant, especially in Mendoza Province (Zanella et al., 2015a).

\subsubsection{Edges of the Cordillera Oriental, central Colombia}

The Cordillera Oriental is an Andean mountain belt in eastern part of Colombia (Fig. 5A, after Mora et al., 2015). Within it, folds and thrusts trend north-northeast, affecting mainly Cretaceous rocks. The geological section shows uplift of Paleozoic to Precambrian basement between reverse faults, as well as major folds within Cretaceous sedimentary rocks, some of which are source rocks for petroleum (Figure 5A). On the western side of the Cordillera, folds and thrusts verge towards the west (Figure 5A) and Cretaceous shales contain layers of calcite beef (white to yellow), which vary in thickness across folds (Figure 5C). At the eastern edge of the Cordillera, in the Macanal Formation (Lower Cretaceous), some beef contains thin layers of yellow pyrite, which have folded (Figure 5B, bottom right), while calcite has grown antitaxially above and below them, filling synclines more than anticlines, indicating a synchronous development with a horizontal shortening. 
In summary, there is good evidence, at both edges of the Cordillera Oriental, for recent overpressure, thrust detachments and multiple veins of compressional calcite beef veins, all within organic-rich mature shale source rocks.

\subsubsection{Paris Basin, northcentral France}

The Paris Basin occupies a large area of northcentral France (Figure 6A0 and consists mainly of Triassic, Jurassic and Cretaceous marine strata, but also some Cenozoic strata (mainly lacustrine) in its central part (Guillocheau et al., 2000). A cross-section (Figure 6A) shows that the basin has undergone some uplift and erosion, especially on its eastern margin. In the past, there have been some descriptions of calcite beef or cone-in-cone structures, mostly within Jurassic shales of the Schistes Carton Formation (lower Toarcian, about $185 \mathrm{Ma}$ ) on the eastern basin margin (e.g. Denaeyer, 1943, 1947), but also within Callovian shales at the northern edge (Voisin, 1999). The Schistes Carton have been subject to much exploration as potential source rocks for oil, and this has revealed the presence of fluid overpressure at several localities. Cobbold et al. (2015) investigated a ditch through the Schistes Carton Formation at Gélaucourt, near Nancy at the eastern edge of the basin (Fig. 6B, left). The ditch (Figure 6B, left) contains many beef veins, several $\mathrm{cm}$ thick and several meters long (Fig. 6B, right). These veins had been identified previously by Denaeyer (1947). They consist mainly of calcite fibers, almost perpendicular to bedding, but they also contain some inclusions of hydrocarbons, which are visible in hand specimens, but especially by scanning electron microscopy (Figure 7B; Cobbold et al., 2015). Recently, by uranium-lead dating of calcite, we have determined the age of formation of this calcite beef to be $155 \mathrm{Ma}$ (Figure 7A). This is about $30 \mathrm{~m}$.y. younger than the stratigraphic age of the host rock (about $185 \mathrm{Ma}$ ). Indeed, the age of the calcite almost coincides with the age of onset of compressional deformation on the eastern edge of the Paris Basin (see Guillocheau

\section{New results: field data for calcite beef in other compressional basins}

4.1. Lourdes, northern Pyrenees, France (locality 22)

At the northern edge of the Pyrenees, a major thrust fault zone separates this mountain range to the south from the Aquitaine Basin to the north. Geological maps of Lourdes (e.g. BRGM, Carte Géologique Détaillée de la France, 1:50 000, sheet XVI-46, 1970) show multiple folds and faults within Mesozoic strata, especially near the town of Lourdes (Choukroune, 1969). Indeed, an oblique view of the Pic du Béout hills, to the east of Lourdes (Figure 8A) shows repetitions of resistant white Aptian-Albian limestones, which dip $30^{\circ}$ to $40^{\circ}$ towards the south. Between the limestones are darker 
cleavage and down-dip lineations. The plains surrounding the hills consist mainly of unconformably

293 overlying Upper Cretaceous flysch. Some of the upper Aptian shale contains layers of fibrous calcite

294 beef (Figure 8B), especially near the village of Aspin-en-Lavedan (Figure 8A). Many of the veins are

295 almost parallel to bedding, whereas younger ones are less steeply dipping and therefore somewhat

296 oblique to bedding. The dipping of the sediments is the result of the compressional deformation from

297 the Late Cretaceous to present day. Because the compression is active since these geological times,

298 beef veins in this area are synchronous with this deformation. Thus, they probably formed once the

299 bedding had rotated and partly as a result of compressional deformation. Our analyses, by scanning

300 electron microscopy (Figure 8C), have revealed steep fractures across a flat-lying vein of calcite beef,

301 the fractures containing much more carbon (orange color) than pure calcite.

302 It also happens that the Aquitaine Basin is hydrocarbon prone, especially beneath low-

303 permeability upper Aptian shale (Biteau \& Canérot, 2007). Thus, there is evidence, around Lourdes,

304 for synchronicity of (1) Late Cretaceous or Cenozoic compressional deformation, (2) generation and

305 accumulation of organic-rich fluids and (3) formation of calcite beef.

4.2. Uinta Basin, Utah (locality 12)

While investigating the presence of bitumen veins in the Uinta Basin, we discovered veins of calcite beef (up to $3 \mathrm{~cm}$ thick), which are common within Eocene shales of the Green River Formation, which are also source rocks for petroleum with several major oil fields. The Uinta Basin is a typical intermontane basin (Fig. 9A). At its northern edge, the basin abuts a major thrust fault, which has uplifted Paleozoic basement (part of the Uinta Mountains). At the northern margin of the basin, overpressure occurs within hydrocarbons of the Altamont-Bluebell oil field (Dubiel, 2003). Elsewhere, exposures of Green River shales (for example, within open mines) contain visible beef, which consist mainly of calcite with dominantly vertical fibers (Fig. 9B). However, in some places the veins consist, not only of calcite, but also of solid hydrocarbons (gilsonite; Fig. 9C). Some veins also contain bitumen between fibers of calcite. Thus, there is evidence for synchronicity of compressional tectonics, maturation of source rocks and growth of beef veins.

In central Asia, the Tian Shan Mountains (up to $7439 \mathrm{~m}$ high) separate the Junggar Basin to the north from the Tarim Basin to the south, and the Fergana Basin to the west (Figure 10A). The Junggar Basin has a long history of development (Jolivet et al., 2010; 2013; Jolivet, 2015), from the Paleozoic onwards, and experienced significant Cenozoic deformation as a result of tectonic reactivation of the Tian Shan intracontinental range (Figure 10B). Our recent fieldwork has shown that calcite beef (several $\mathrm{cm}$ thick) and cone-in-cone (Figure 10C) occur frequently within mid-Jurassic strata (mainly 
the Xishanyao and Totounhe Formations), which crop out in the Junggar Basin on its southern margin

330 (Wusu and Totoun localities) or eastern edge (Kalameili region), along a series of thrust faults and

331 folds, related to the development of the Tian Shan and Altai ranges, respectively. Inside the Tian Shan

332 range itself, cone-in-cone structures occur at Nileke (Figure 10D), at the eastern tip of the intra-

333 mountain Yili Basin within the Middle Jurassic Totounhe Formation (Figures 1 and 10). This area has

334 been subject to large-scale thrusting, during Neogene growth of the northern Tian Shan subrange.

335 Finally, to the west in the intramountain Issik-Kul Basin (Kyrgyzstan), bedding-parallel beef with

336 vertical fibers (Figure 10E, F) occur in Jurassic strata along the southern edge of the basin, which has

337 been subject to Cenozoic compressional deformation in the Terzkey range (Figsure 1 and 10). The

338 proximity between our beef occurrences and major thrust faults suggests that beef and the Cenozoic

339 reactivation of the basin are synchronous.

340 At all of these localities, the beef or cone-in-cone occur within organic-rich fine-grained alluvial

341 plain deposits (Heilbronn, 2014). In the Junggar and Yili basins, they are also close to coal layers,

342 which are several metres thick. At some localities, especially in the Yili and Issik-Kul basins, the

343 calcite beef is close to iron-rich sandy layers of probable diagenetic origin. At Issik-Kul, strong

344 uranium enrichment of the Jurassic series (Kaji Sai mine) containing the beef again indicates post-

345 sedimentary fluid circulation. In the Junggar Basin, the main source rocks for oil are the upper

346 Permian, Upper Triassic and Middle Jurassic detrital series (Jiao et al., 2007). The occurrence of

347 calcite beef within the Middle Jurassic series and the systematic association between beef and organic-

348 rich siltstone or coal layers suggests a link between hydrocarbon source rocks and calcite beef.

349 In the southern Junggar Basin (locality 8, Figure 1), Jiao et al. (2007) (Fig. 2) described and

350 illustrated thin bedding-parallel veins of calcite within the upper Permian Lucaogou Formation near

351 Urumqi. These authors did not refer to fibrous calcite (beef) or cone-in-cone, but they showed many

352 examples of solid hydrocarbons within cavities, the Lucaogou Formation being a mature petroleum

353 source rock.

4.4. Appalachian Mountains, United States (locality 2, Fig. 1).

In the eastern US (Figure. 11A), the Appalachian Mountains trend northeast-southwest and consist mainly of Paleozoic strata, folds and thrusts (Gilman \& Metzger, 1967; Evans, 1995; Tobin et al., 1996). At the southwestern end of the mountains, a major unconformity underlies Cretaceous strata, which form a broad anticline (Figure 11A). This provides good evidence for Late Cretaceous or Cenozoic reactivation of the mountain belt. Indeed, even today, the belt is subject to earthquakes, resulting from compressive stress (Heidbach et al., 2009), which appears to derive from ridge-push of the Atlantic spreading center. Veins of calcite beef and bitumen (e.g. Figure 11B) occur within the Devonian Marcellus Shale (Gale et al., 2014; Aydin \& Engelder, 2014). Some of the veins are undulating and have additional lenses within synclines (Gale et al., 2014, their fig. 9E). Even today, 
the Marcellus Shale is a source rock for oil and locally reaches overpressure (Aydin \& Engelder, 2014), possibly as a result of long-term and recent burial. Furthermore, the layers of Marcellus Shale have acted as detachments for thrust faults in the Appalachians (Aydin \& Engelder, 2014). Thus, the Appalachians, like other areas, provide evidence for synchronicity of (1) compressional deformation, (2) generation of organic-rich fluids and (3) formation of calcite beef. A possible problem in the Appalachians is to date these features, which may have started long ago, but still be occurring today.

\section{Discussion}

Because beef veins seem to be proxies for natural hydraulic fracturing in rocks, especially within source rocks for petroleum, the studies of such fractures are key to the understanding of such geological processes and for the migration and interactions between fluids and rocks. Their formation depends on 2 main phases: (1) the generation of the fracture and (2) the filling of the fracture.

For the initiation of the natural hydraulic fractures, and thus the initiation of beef veins, the theory and the experiments of fracturing demonstrate that horizontal (or bedding-parallel) fractures can be generated, due to a distributed fluid overpressure (Cobbold \& Rodrigues, 2007; Mourgues et al. 2011; our review; Zanella et al. 2014a). Nevertheless, previous reviews (Cobbold et al. 2003; Gale et al. 2014) and more recent and local studies (e.g. Rodrigues et al. 2007; Zanella et al. 2014a, 2014b, 2015a, 2015b; Weng et al. 2017; Ukar et al. 2017; Ukar et al. 2018) have shown that the natural hydraulic fracturing often occurred within sedimentary basins which experienced a compressive tectonic history. Moreover, according to several previous studies, the timing of development of beef veins was synchronous with a compressive period in the basin. This is, in particular, well-illustrated for the Neuquén Basin (Rodrigues et al. 2009; Zanella et al. 2015a; Ukar et al. 2017; Ukar et al. 2018), the Wessex Basin (Zanella et al. 2015b), the Bristol Chanel (Weng et al. 2017) and the Magallanes Basin (Zanella et al., 2014). In our study, we demonstrate that this observation is also true for the development of beef veins in the Paris Basin (beef veins dated at $155 \mathrm{Ma}$ ), in the northern Pyrenees, in the Uinta Basin, in the Tian Shan Mountains and in the Appalachian Mountains. In view of all of these observations and conclusions, we ask some questions: even if in theory the compressive tectonic stress is not necessary to develop bedding-parallel natural hydraulic fractures, is, in nature, this stress crucial for the development of such fractures? Is the fluid overpressure, generated by hydrocarbons, enough to induce hydraulic fracturing of shales?

We thus propose that compressional tectonic stress is one of the key parameters in the development of bedding-parallel veins in shales. This could have major consequences for the understanding of fluid migration in sedimentary rocks, because of the historical complexity of such geological processes. Concerning the generation of hydrocarbons, even if tectonic activity has a big role, the maturation of organic matter, which leads to the development of distributed fluid 
overpressures and then to natural hydraulic fracturing, is still the main parameter. Indeed, as already demonstrated, during the maturation of the source rock a part of the solid framework (the organic matter) will be transform into fluid (hydrocarbons), implying a collapse and a load transfer responsible of the increasing of the pore fluid pressure (Zanella et al. 2014a). These fractures are always within or near source rocks for petroleum (Cobbold et al. 2013; Gale et al. 2014). All of our examples respect the previous observations. So, as already suggested by previous authors (Ukar et al. 2017, 2018; Zanella et al. 2014b; Zanella et al. 2015a; Zanella et al. 2015b), the link between the presence of beef veins and organic matter is strong. Moreover, the degree of maturity of the source rock is a key parameter for the development of beef veins and other tectonic structures, such as detachments, as demonstrated in the Magellan Basin (Zanella et al. 2014b). In this basin, Zanella et al. (2014b) also demonstrated that there is a link between beef vein composition and the degree of maturity of the source rock. Thus, we infer that this natural fluid generation process is the main driver for inducing fluid overpressure in mature shales, but needs to be assisted by another force, such as the compressive tectonic stress, to be able to induce natural fracturing of the host rocks.

Concerning the filling of the fracture and thus the cementation and growth of the bedding-parallel fractures, other mechanisms have to be involved to precipitate minerals. Indeed, the opening of the fractures is in mode 1 and is facilitated by a horizontal compressive stress. Nevertheless, the force of crystallization also participates to pushing outward the vein walls. Currently, which of these two processes plays the dominant role is not yet known.

\section{Conclusions}

Beef veins (BPV) are common in or near source rocks for petroleum. The study of such geological evidences can help to understand the mechanisms involved in their formation: (1) the generation of the fracture and (2) the opening of the fracture, as well as the migration of fluids in sedimentary basins. Studies of beef vein occurrences around the world have led us to conclude that it is especially common within foreland basins. Here we have reviewed examples (or described new ones) from the Wessex Basin (UK), the Neuquén Basin (Argentina), the Cordillera Oriental (Colombia), the Uinta Basin (USA), the Paris Basin (France), the northern Pyrenees (France), the Tian Shan Mountains (central Asia) and the Appalachian Mountains (USA). However, we have discovered similar beef within other localities of foreland basins (some of which are visible in Fig. 1).

In this review, we demonstrate that the development of beef veins occurs worldwide within or near source rocks for petroleum and during a period of hydrocarbon generation. It is now becoming clearer that the maturation of the organic matter can lead to fluid overpressures. Beef veins (and more generally the natural hydraulic fractures) can therefore be used as proxy to determine very quickly if a 
source rock was or has been mature. On a global scale, many foreland basins contain source rocks, near active or ancient mountain belts, the latter of which may have been reactivated by recent tectonic stress. Many such basins contain enough organic material to have acted as source rocks for petroleum systems, especially where recent burial has generated sufficiently high temperatures. In some examples (such as the Neuquén Basin of Argentina), next to subduction-zone systems, magmatic intrusions or extrusions have added heat and facilitated the maturation of the source rocks, also during compressional tectonic activity.

The timing of beef vein generation in foreland basins is always coeval with shortening periods, due to compressive tectonic stress. Thus, even if the theory and the experiments of fracturing demonstrate that bedding-parallel fractures can be generated only with a distributed fluid overpressure, the beef veins formation seems to require an external tectonic stress to develop in nature. The filling of the fractures is likely related to force of crystallization, during the compressive period and facilitates the vertical opening of veins.

\section{Acknowledgements}

During the years 2005 to 2012, Ian West of Southampton University introduced us to some of the best beef localities in the Wessex Basin, along the coast of southern England (West, 2015). We thank Tony Boassen (StatoilResearch Centre, Trondheim), for help with scanning electron microscopy of calcite beef from the Wessex Basin and Neuquén. We also thankAndres Mora of Ecopetrol for showing Peter Cobbold some beef veins at the eastern edge of the Cordillera Oriental, Colombia (Fig. 5). Fieldwork in central Asia was funded by the DARIUS group. Elsewhere, much of the fieldwork and experimental work, as well as $\mathrm{PhD}$ studies, were funded by Statoil (Norway). DC acknowledges support from Science Foundation Ireland under Grant Number 15/IACA/3365.

\section{References}

Aydin, M.G., Engelder, T., 2014. Revisiting the Hubbert-Rubey pore pressure model for overthrust faulting: Inferences from bedding-parallel detachment surfaces within Middle Devonian gas shale, the Appalachian Basin, USA. J. Struct. Geol. 69, 519-537.

Barker, S.L.L., Cox, S.F., Eggins, S.M., Gagan, M.K., 2006. Microchemical evidences for episodic growth of antitaxial veins during fracture-controlled fluid flow. Earth and Planetary Science Letters 250, 331-344.

Biteau, J.-J., Canérot, J., 2007. La Chaîne des Pyrénées et ses avant-pays d'Aquitaine et de l'Ebre: systèmes pétroliers et gisements d'hydrocarbures. Géologues 155, 29-41. 
Bons, P., 2001. Development of crystal morphology during unitaxial growth in a progressively widening vein: I. The numerical model. Journal of Structural Geology, 23(6-7): 865-872.

Bons, P.D., Elburg, M.A. and Gomez-Rivas, E., 2012. A review of the formation of tectonic veins and their microstructures. Journal of Structural Geology, 43: 33-62.

Bons, P.D., Jessell, M.W.,1997. Experimental simulation of the formation of fibrous veins by localised dissolution-precipitation creep. Mineralogical Magazine 61, 53-63.

Bradbury, K.K., Davis, C.R., Shervais, J.W., Janecke, S.U., Evans, J.P., 2015. Composition, alteration, and texture of fault-related rocks from Safod core and surface outcrop analogs: evidence for deformation processes and fluid-rock interactions. Pure and Applied Geophysics 172, 1053-1078.

Buckland, W., De la Beche, H.T., 1835. On the geology of the neighbourhood of Weymouth and the adjacent parts of the coast of Dorset. Trans. Geol. Soc. Lond., s2 4, 1-46.

Chatellier, J.-Y., 2013. How to maximize the use of TMAX, compositional ratios and stable carbon isotopes to accurately infer the maturity of a shale. Tight Oil Canada, 2013.

Choukroune, P., 1969. Sur la presence, le style et l'âge des tectoniques superposées dans le Crétacé nord-pyrénéen de la région de Lourdes (Hautes-Pyrénées). Bulletin du Bureau de Recherches Géologiques et Minières Section I, No. 2, 11-20.

Cobbold, P.R., 2013. Geological evidence for fluid overpressure in mature source rocks within foreland basins of the Americas. American Association of Petroleum Geologists, International Conference and Exhibition, Cartagena, Colombia, 8-11 September. Search and Discovery Article \#30291.

Cobbold, P.R., Castro, L., 1999. Fluid pressure and effective stress in sandbox models. Tectonophysics 301, 1-19.

Cobbold, P.R., Durand, S., Mourgues, R., 2001. Sandbox modelling of thrust wedges with fluidassisted detachments. Tectonophysics 334, 245-258.

Cobbold, P.R., Rodrigues, N., 2007. Seepage forces, important factors in the formation of horizontal hydraulic fractures and bedding-parallel fibrous veins ("beef" and "cone-in-cone”). Geofluids 7 , 313-332.

Cobbold, P.R., Zanella, A., Ruffet, G., Rodrigues, N., Loseth, H., 2013. Bedding-parallel fibrous veins (beef and cone-in-cone): Worldwide occurrence and possible significance in terms of fluid overpressure, hydrocarbon generation and mineralization. Mar. Petrol. Geol. 43, 1-20.

Cobbold, P., Zanella, A., Fourdan, B., Néraudeau, D., Gouttefangeas, F., 2015. Natural hydraulic fractures in the Eastern Paris Basin. Bull. Inf. Géol. Bassin Paris 52 (2), 23-30.

David, L., 1952. Présence de la structure “beef” et “cone-in-cone” dans le Crétacé de l'EstConstantinois (Algérie). Comptes Rendus Sommaires de la Société Géologique de France 3, 51 52. 
Denaeyer, M.-E., 1943. Les cone-in-cone de la France métropolitaine et d'outre-mer. Bull. Soc. Fr. Minéral. 66 (1-6), 173-221.

Denaeyer, M.-E., 1947. Les gisements de cone-in-cone de France et de Grande-Bretagne. Première Partie. Bulletin de la Société Belge de Géologie, Paléontol. Hydrol. 56, 21-46.

Dubiel, R.F., 2003. Geology, depositional models, and oil and gas assessment of the Green River total petroleum system, Uinta-Piceance Province, Eastern Utah and Western Colorado. In: Petroleum systems and geologic assessment of oil and gas in the Uinta-Piceance Province, Western Colorado. U.S. Geological Survey, Digital Data Series DDS-69-B, 1-41.

Evans, M.A., 1995. Fluid inclusions in veins from the Middle Devonian shales: A record of deformation conditions and fluid evolution in the Appalachian Plateau. Geol. Soc. Am. Bull. 107 (3), 327-339.
Fischer, M.P., Higuera-Diaz, I.C., Evans, M.A., Perry, E.C., Lefticariu, L., 2009. Fracture-controlled paleohydrology in a map-scale detachment fold: Insights from the analysis of fluid inclusions in calcite and quartz veins. J. Struct. Geol. 31, 1490-1510.

Fitz-Diaz, E., Hudleston, P., Siebenaller, L., Kirschner, D., Camprubi, A., Tolson, G., Puig, T.P., 2011. Insights into fluid flow and water-rock interaction during deformation of carbonate sequences in the Mexican fold-thrust belt. J. Struct. Geol. 33, 1237-1253.

Gale, J.F.W., Laubach, S.E., Olson, J.E., Eichhubl, P., Fall, A., 2014. Natural fractures in shale: a review and new observations. Am. Assoc. Petrol. Geol. Bull, 98 (11), 2165-2216.

Gely, J-P., Hanot, F., 2014. Le bassin parisien : un nouveau regard sur la géologie. In: Bulletin d'information des géologues du bassin de Paris, 9, 229 pp.

Gilman, R.A., Metzger, W.J., 1967. Cone-in-cone concretions from western New York. J. Sed. Petrol. $37,87-95$.

Gressier, J.B., Mourgues, R., Bodet, L., Matthieu, J.Y., Galland, O., Cobbold, P.R., 2010. Control of pore fluid pressure on depth of emplacement of magmatic sills: An experimental approach. Tectonophysics 489, 1-13.

Guillocheau, F., Robin, C., Allemand, P., Bourquin, S., Brault, N., Dromart, G., Friedenberg, R.,

Heilbronn, G., 2014. Evolution paléogéographique et paléotopographique du Tian Shan Chinois au Mésozoïque. PhD thesis, Univ. Rennes, 267 pp.

Hilgers, C., Koehn, D., Bons, P.D. and Urai, J.L., 2001. Development of crystal morphology during unitaxial growth in a progressively widening vein: II. Numerical simulations of the evolution of antitaxial fibrous veins. Journal of Structural Geology, 23(6-7): 873-885. 
Hillier, R.D., Cosgrove, J.W., 2002. Core and seismic observations of overpressure-related deformation within Eocene sediments of the Outer Moray Firth, UKCS. Petroleum Geoscience 8, 141-149.

Jiao, Y.Q., Wu, L.Q., He, M.C., Mason, R., Wang, M.F., Xu, Z.C., 2007. Occurrence, thermal evolution and primary migration processes derived from studies of organic matter in the Lucaogou source rock at the southern margin of the Junggar Basin, NW China. Science in China, Series D - Earth Sciences 50, 114-123.

Jolivet, M., Dominguez, S., Charreau, J., Chen, Y., Li, Y., Wang, Q., 2010. Mesozoic and Cenozoic tectonic history of the central Chinese Tian Shan: Reactivated tectonic structures and active deformation. Tectonics 29, 1-30.

Jolivet, M., Heilbronn, G., Robin, C., Barrier, L., Bourquin, S., Guo, Zh., Jia, Y., Guerit, L., Yang, W., $\mathrm{Fu}, \mathrm{B} ., 2$ 2013. Reconstructing the Late Palaeozoic - Mesozoic topographic evolution of the Chinese Tian Shan: available data and remaining uncertainties. Advances in Geosciences 37, 718.

Jolivet, M., 2015. Mesozoic tectonic and topographic evolution of Central Asia and Tibet: a preliminary synthesis. In: Brunet, M.-F., McCann, T. \& Sobel, E.R. (eds) Geological evolution of Central Asian Basins and the Western Tien Shan Range. Geol. Soc. London Sp. Publ., 427, http://doi.org/10.1144/SP427.2

Kemp, J., 2014. The Big One: Russia's Bazhenov shale. http://www.reuters.com/article/2014/07/18/us-russia-shale-kemp-idU.

Kershaw, S., Guo, L. 2016. Beef and cone-in-cone calcite fibrous cements associated with the endPermian and end-Triassic mass extinctions: Reassessment of processes of formation. J. Palaeogeog. 5 (1), 28-42.

Keulen, N. T., den Brok, S.W.J., Spiers, C.J., 2001. Force of crystallisation of gypsum during hydration of synthetic anhydrite rock. 13th DRT conference, Deformation Mechanisms, Rheology, and Tectonics, Noordwijkerhout, The Netherlands.

Kowal-Linka, M., 2010. Origin of cone-in-cone calcite veins during calcitization of dolomites and their subsequent diagenesis: A case study from the Gogolin Formation (Middle Triassic), SW Poland. Sed. Geol. 224, 54-64.

Kozlowski, E.E., Cruz, C.E., Sylwan, C., 1998. Geologia estructural de la zona de Chos Malal, Cuenca Neuquina, Argentina. In: XIII Congreso Geologico Argentino y III Congreso de Exploracion de Hidrocarburos, Buenos Aires, Actas 1, 15-26.

Labaume, P., Sheppard, S.M.F., Moretti, I., 2001. Fluid flow in cataclastic thrust fault zones in sandstones, Sub-Andean Zone, southern Bolivia. Tectonophysics 340, 141-172.

Lamb, S., 2004. Devil in the mountain. A search for the origin of the Andes. Princeton University Press 335 pp. 
Lang, W.D., Spath, L.F., Richardson, W.A., 1923. Shales-With-'Beef', a sequence in the Lower Lias of the Dorset Coast. Q. J. Geol. Soc. Lond.79, 47-99.

Le Breton, E., Cobbold, P.R., Zanella, A., 2013. Cenozoic reactivation of the Great Glen Fault, Scotland: additional evidence and possible causes. J. Geol. Soc. Lond. 170, 403-415, doi: 10.1144/jgs2012-067.

Lee, G.W., 1920. The Mesozoic rocks of Applecross, Raasay and North-East Skye. H.M. Geological Survey, Scotland, $93 \mathrm{pp}$.

Lemrabott, A., Cobbold, P.R., 2010. Physical modeling of fluid overpressure and compaction during hydrocarbon generation in source rock of low permeability. Search and Discovery, Article \#40518.

Leythaeuser, D., Littke, R., Radke, M., Schaefer, R.G., 1988. Geochemical effects of petroleum migration and expulsion from Toarcian source rocks in the Hils Syncline area, NW-Germany. In: Mattavelli, L. \& Novelli, L. (Eds.), Advances in Organic Geochemistry 1987. Organic Geochemistry 13, 489-502.

Lilloe-Olsen, T., Bang, N.A., 2012. DNO and Tawke in Kurdistan: How an Iraq oil giant has emerged. Oil \& Gas Journal 1-19. http://www.ogj.com/articles/print/vol-110/issue-2/explorationdevelopmet/dno-and-tawke-in...

Macsotay, O., Erlich, R.N., Peraza, T., 2003. Sedimentary structures of the La Luna, Navay and Querecual Formations, Upper Cretaceous of Venezuela. Palaios 18, 334-348.

Mahboubi, A., Moussavi-Harami, R., Collins, R.B., Muhling, J.R., 2010. Petrography and geochemical signatures in cracks filling calcite sequences in septarian concretions, Sanganeh Formation, Kopet-Dagh Basin, NE Iran. J. Appl. Sci. 10, 526-534.

Maillot, H., Bonte, A., 1983. Cone-in-cone texture from Deep Sea Drilling Project Leg 71, Site 511, Falkland Plateau, South Atlantic Ocean. Initial Reports of the Deep Sea Drilling Project 71(1), 345-349.

Mangenot, X., Gasparrini, M., Rouchon, V., Bonifacie, M., 2018. Basin-scale thermal and fluid flow histories revealed by carbonate clumped isotopes $(\Delta 47)$-Middle Jurassic carbonates of the Paris Basin depocentre. Sedimentology, 65(1), 123-150.

Marques, F.O., Nogueira, F.C.C., Bezerra, F.H.R., Castro, D.L. de, 2014. The Araripe Basin in NE Brazil: An intracontinental graben inverted to a high-standing horst. Tectonophysics 630, 251264.

Marshall, J.D., 1982. Isotopic composition of displacive fibrous calcite veins; reversals in pore-water composition trends during burial diagenesis. J. Sediment. Petrol. 52, 615-630.

Martinius, A.W., Hegner, J., Kaas, I., Bejarano, C., Mathieu, X., Mjoes, R., 2012. Sedimentology and depositional model for the Early Miocene Oficina Formation in the Petrocedeño Field (Orinoco heavy-oil belt, Venezuela). Mar. Petrol. Geol. 35, 354-380.

Means, W. and Li, T., 2001. A laboratory simulation of fibrous veins: some first observations. Journal 
of Structural Geology, 23(6-7): 857-863.

Mora, A., Blanco, V., Naranjo, J., Sanchez, N., Ketcham, R.A., Rubiano, J., Stockli, D.F., Quintero, I., Nemcok, M., Horton, B.K., Davila, H., 2013. On the lag time between internal strain and basement involved thrust induced exhumation: The case of the Colombian Eastern Cordillera. J. Struct. Geol. 52, 96-118.

Mora, A., Casallas, W., Ketcham, R.A., Gomez, D., Parra, M., Namson, J., Stockli, D., Almendral, A., Robles, W., Ghorbal, B., 2015. Kinematic restoration of contractional basement structures using thermokinematic models. Am. Assoc. Petrol. Geol. Bull. 99 (8), 1575-1598.

Mourgues, R., Cobbold, P.R., 2003. Some tectonic consequences of fluid overpressures and seepage forces as demonstrated by sandbox modeling. Tectonophysics 376, 75-97.

Nollet, S., Urai, J.L., Bons, P.D., Hilgers, C., 2005. Numerical simulations of polycrystal growth in veins. Journal of Structural Geology 27, 217-230.

Nollet, S., Koerner, T., Kramm, U., Hilgers, C., 2009. Precipitation of fracture fillings and cements in the Buntsandstein (NW Germany). Geofluids 9, 373-385.

Nomura, S.F., Sawakuchi, A.O., Bello, R.M.S., Méndez-Duque, J., Fuzikawa, K., Giannini, P.C.F., Dantas, M.S.S., 2014. Paleotemperatures and paleofluids recorded in fluid inclusions from calcite veins from the northern flank of the Ponta Grossa dyke swarm: Implications for hydrocarbon generation and migration in the Paraná Basin. Mar. Petrol. Geol. 52, 107-124.

Parnell, J., Blamey, N.J.F., Costanzo, A., Feely, M., Boyce, A.J., 2014. Preservation of

Mesoproterozoic age deep burial fluid signatures, NW Scotland. Mar. Petrol. Geol. 55, 275-281.

Pearson, P.N., Nicholas, C.J., Singano, J.M., Bown, P.R., Coxall, H.K., van Dongen, B.E., Huber, B.T., Karega, A., Lees, J.A., MacLeod, K., McMillan, I.K., Pancost, R.D., Pearson, M., Msaky, E., 2006. Further Paleogene and Cretaceous sediment cores from the Kilwa area of coastal Tanzania: Tanzania Drilling Project Sites 6-10. J. Afr. Earth Sci. 45, 279-317.

Richardson, W.A., 1923. Petrology of the Shales-with-“Beef.” Q. J. Geol. Soc. Lond. 79, 88-99. Rodrigues, N., Cobbold, P.R., Loseth, H., Ruffet, G., 2009. Widespread bedding-parallel veins of fibrous calcite ("beef”) in a mature source rock (Vaca Muerta Fm, Neuquén Basin, Argentina): evidence for overpressure and horizontal compression. J. Geol. Soc. Lond. 166, 695-709, doi 10.1144/0016-76492008-111.

Rybak-Ostrowska, B., Konon, A., Nejbert, K., Kozlowski, A., 2014. Bedding-parallel calcite veins in the Holy Cross Mountains Fold Belt, central Poland. Geological Quarterly 58 (1), 99-116.

Silva, A.L. Da, 2003. Estratigrafia física e deformação do sistema lacustre carbonático (AptianoAlbiano) da Bacia do Araripe em afloramentos selecionados. Dissertação de Mestrado, Univ. Fed. Pernambuco, Pós-graduação em Geociências, 118 pp. veins. Geofluids 14, 45-57. 
Suchy, V., Dobes, P., Filip, J., Stejskal, M., Zeman, A., 2002. Conditions for veining in the Barrandian Basin (Lower Palaeozoic), Czech Republic: evidence from fluid inclusion and apatite fission track analysis. Tectonophysics 348, 25-50.

Tarney, J., Schreiber, B.C., 1976. Cone-in-cone and beef-in-shale textures from DSDP site 330, Falkland Plateau, South Atlantic. In: Barker, P.F., Dalziel, I.W.D. et al. (Eds), Initial Reports of the Deep Sea Drilling Project. U.S. Government Printing Office, Washington, D.C. 36, 865-870.

Tobin, K.J., Walker, K.R., Steinhauff, D.M., Mora, C.I., 1996. Fibrous calcite from the Ordovician of Tennessee: preservation of marine oxygen isotopic composition and its implications.

$$
\text { Sedimentology 43, 235-251. }
$$

Trabucho-Alexandre, J., Dirkx, J., Veld, H., Klaver, G., De Boer, P.L., 2012. Toarcian black shales in the Dutch Central Graben: Record of energetic, variable depositional conditions during an oceanic anoxic event. J. Sed. Res. 82, 104-120.

Ukar, E., Lopez, R.G., Gale, J.F., Laubach, S. E., Manceda, R., 2017. New type of kinematic indicator in bed-parallel veins, Late Jurassic-Early Cretaceous Vaca Muerta Formation, Argentina: EW shortening during Late Cretaceous vein opening. Journal of Structural Geology, 104, 31-47.

Ukar, E., López, R., Hryb, D., Gale, J.F., Manceda, R., Fall, A., Brisson, I., Hernandez-Bilbao, E., Weger, R., Marchal, D., Zanella, A., Lanusse, I., 2018. Natural fractures in the Vaca Muerta Formation: from core and outcrop analog observations to subsurface models. AAPG Memoir, 120, (submitted).

Underhill, J.R., Stoneley, R., 1998. Introduction to the development, evolution and petroleum geology of the Wessex Basin. In: Geol. Soc., London, Sp. Publ. 133, 1-18.

Vera, E.A.R., Folguera, A., Valcarce, G.Z., Bottesi, G., Ramos, V.A., 2014. Structure and development of the Andean system between 36 and 39 S. Journal of Geodynamics, 73, 34-52. Voisin, L., 1999. Le "beef” de Chaumiau(08). Bull. d'Inform. Géol. Bassin de Paris 36 (2), 13-16.

Volk, H., Horsfield, B., Mann, U., Suchy, V., 2002. Variability of petroleum inclusions in vein, fossil and vug cements - a geochemical study in the Barrandian Basin (Lower Palaeozoic, Czech Republic). Organic Geochemistry 33, 1319-1341.

Watts, N.L., 1978. Displacive calcite: Evidence from recent and ancient calcretes. Geology 6, 699703.

Weger, R.J., Murray, S.T., McNeill, D.J., Swart, P.K., Eberli, G.P., Rodriguez Blanco, L., Tenaglia, M., Rueda, L., 2018. Paleo thermometry and distribution of calcite beef in the Vaca Muerta Formation, Neuquén Basin, Argentina. AAPG Bulletin, (submitted).

West, I.M., 2015. Geology of the Wessex coast of southern England - the World Heritage Jurassic Coast - and more. Internet page: http://www.southampton.ac.uk/ imw/index.htm.

Woodland, B.G., 1964. The nature and origin of cone-in-cone structure. Fieldiana: Geology 13 (4), 187-305.

Zanella, A., Cobbold, P.R., Le Carlier de Veslud, C., 2014a. Physical modelling of chemical 
compaction, overpressure development, hydraulic fracturing and thrust detachments in organicrich source rock. Mar. Petrol. Geol. 55, 262-274. http://dx.doi.org./10.1016/j.marpetgeo.2013.12.017.

696 Zanella, A., Cobbold, P.R., Rojas, L., 2014b. Beef veins and thrust detachments in Early Cretaceous source rocks, foothills of Magallanes-Austral Basin, southern Chile and Argentina: structural evidence for fluid overpressure during hydrocarbon maturation. Mar. Petrol. Geol. 55, 250-261. http://dx.doi.org/10.1016/j.marpetgeo.2013.10.006.

Zanella, A., Cobbold, P.R., Ruffet, G., Leanza, H.A., 2015a. Geological evidence for fluid overpressure, hydraulic fracturing and strong heating during maturation and migration of hydrocarbons in Mesozoic rocks of the northern Neuquén Basin, Mendoza Province, Argentina. J. S. Am. Earth Sci. 62, 229-242.

Zanella, A., Cobbold, P.R., Boassen, T., 2015b. Natural hydraulic fractures in the Wessex Basin, SW England: widespread distribution, composition and history. Mar. Petrol. Geol. 68, 438-448.

Zhang, B., Yin, C.Y., Gu, Z.D., Zhang, J.J., Yan, S.Y., Wang, Y., 2015. New indicators from beddingparallel beef veins for the fault valve mechanism. Science China: Earth Sci., doi: 10.1007/s11430-

\section{Figure captions}

Table. 1. Global distribution of compressional basins, where calcite beef or cone-in-cone occur. For localities (numbers at left), see Figure 1. Not all references are to previous descriptions of calcite beef.

Figure 1. Map showing distribution of calcite beef (bedding-parallel veins), either within Mesozoic or

Cenozoic sedimentary rocks (light triangles) or within Paleozoic sedimentary rocks (dark triangles). The numbers next to the triangles refer to the localities in Table 1.

Figure 2. A. Physical model of horizontal hydraulic fracturing with no deformation (after Zanella et al., 2014a); B. Physical model of horizontal hydraulic fracturing with shortening (after Zanella et al., 2014a); C. Cross-section of a 3-D physical model showing the different styles of deformation due to the propagation of a detachment linked to overpressure development (after Zanella et al., 2014a).

Figure 3. A. Geological map and cross-section of the Wessex Basin, southwestern England (after Zanella et al. 2015B, modified from Underhill et al. 1998). B. folded and faulted beef veins, the thickness of which is again variable, especially across the main reverse fault (center). C. Locally folded beef, the thickness of which is variable (thicker in syncline, thinner in anticline). D. Steeply dipping but curved calcite fibers, which comprise a layer of beef. (scales: pen: $14 \mathrm{~cm}$; coin diameter: 
732 Figure 4. A. Calcite beef in the Neuquén Basin, Argentina (white locality 4, Figure 1) (after

733 Rodrigues et al., 2009). The Landsat image (left) shows sub-Andean folds, trending north-northwest.

734 Field observations (bottom right) show that beef is common in the Vaca Muerta Formation at various scales. B. Geological section through the fold and thrust belt of the Neuquén Basin (located with the red line in Figure 4A.) (after Vera et al., 2014).

Figure 5. A. Geological map and cross-section, showing the main structures of the eastern Cordillera (after Mora et al., 2013, 2015). B. Calcite beef (bedding-parallel) veins (white to yellow), which vary in thickness across folds (Cobbold, 2013). C. On the western side of the Cordillera, near Villeta, folds and thrusts verge westward and Cretaceous shales contain layers of calcite beef. D. At the eastern edge of the Cordillera, in the Macanal Formation (Lower Cretaceous) near Villavicencio, some beef contains thin layers of yellow pyrite, which are folded, while calcite has grown epitaxially above and below them, filling in synclines more than anticlines. (scales: coin diameter: $2.2 \mathrm{~cm}$ ).

Figure 6. A. Geological map of the Paris Basin (after Gely and Hanot, 2014; Mangenot et al. 2018). The basin has an elliptical shape with a long axis trending approximately northeast-southwest. The line of section is indicated in red. B. Gélaucourt, near Nancy, ehere ditches have exposed Liassic shales of the Schistes Carton Formation (lower Toarcian, Denaeyer, 1943; ca $185 \mathrm{Ma}$ ), which contain abundant veins of fibrous calcite beef (hammer length: $33 \mathrm{~cm}$ ). C. Calcite beef from the Toarcian at Gélaucourt (coin diameter: $2.3 \mathrm{~cm}$ ).

Figure 7. A. U-Pb Tera-Wasserburg calcite lower intercept age of $155 \pm 19 \mathrm{Ma}$ (Oxfordian) for the formation of the calcite beef (Chew et al., work in progress). B\&C. Scanning electron microscopy (SEM) analyses of calcite beef (bedding-parallel veins) from the Liassic "Schistes Carton" near Gélaucourt in the Paris Basin (see Fig. 6). Scanning electron microscopy (SEM) has yielded significant quantities of calcium (B) and carbon (C), which are typical of calcite. However, the amount of carbon is locally greater (pink, top right), due to inclusions of hydrocarbons within the calcite crystals (Cobbold et al., 2015).

Figure 8. Calcite beef near Lourdes, at the northern edge of the Pyrenees (white locality 22, Figure 1).

A. Google Earth oblique view of the Pic du Béout hills (1530 m high, near the southeast end of Lourdes city), shows repetitions of white, thick, resistant layers of Aptian-Albian limestones, which dip at about $30^{\circ}$ to $40^{\circ}$ to the south forming scarps. The white line represents the main thrust fault. B. Road outcrop showing fibrous calcite beef (bedding-parallel veins) in upper Aptian shales (coin diameter: $2.3 \mathrm{~cm}$ ). C. Scanning electron microscopy and the repartition of the carbon, the calcium and 
the oxygen in the beef vein.

Figure 9. Calcite beef and bitumen in the Uinta Basin, Utah (white locality 13, Fig. 1). A. A simplified geological section (top, north-northeast to southwest, after Dubiel, 2003) shows the asymmetric structure of the basin. B. Outcrop, discovered in 2009, showing gently dipping beds of the Green River Formation (grey) and numerous veins, either of pure fibrous calcite (orange, left), or of hammer) (hammer length: $33 \mathrm{~cm}$ ).

Figure 10. Calcite beef around the Tian Shan Mountains, central Asia (localities 30 to 32, Fig. 1). A: Topographic and tectonic map of the Tian Shan and Junggar region (modified from Jolivet et al.,

778 2013). B: Geological cross-section (approximately north-south) of the Junggar Basin (red line, A). C:

779 Cone-in-cone structures in the Xishanyao Formation (Middle Jurassic) at Wusu (top) (lens cover

780 diameter: $5.2 \mathrm{~cm}$ ). D: Cone-in-cone structures in the Totounhe Formation (Middle Jurassic) at Nileke

781 (top). E and F: bedding-parallel calcite beef in Jurassic strata at Kaji Sai (Issik Kul Basin, top) (pen: 14 $782 \mathrm{~cm})$.

784 Figure 11. Calcite beef and bitumen in the Appalachian Mountains, US (locality 2, Figure 1). A.

785 Simplified geological map showing the Paleozoic thrust belt (red), trending northeast-southwest. At its

786 southwestern end, a major unconformity marks the base of Cretaceous strata (green), which

787 nevertheless form a broad anticline, plunging southwest. Red dot refers to Fig. 11B. B. Veins of calcite 788 beef (bedding-parallel veins) and bitumen occurring within the Marcellus Shale (Devonian) along

789 Route 250, Highland County, Virginia $\left(38^{\circ} 19^{\prime} 34.31^{\circ} \mathrm{N} ; 79^{\circ} 26^{\prime} 32.29^{\circ} \mathrm{W}\right.$, south-southeast of

790 Pittsburgh, Pennsylvania) (coin diameter: $2.4 \mathrm{~cm}$ ).

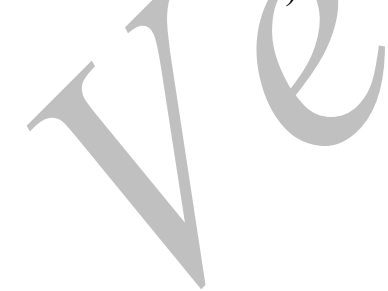




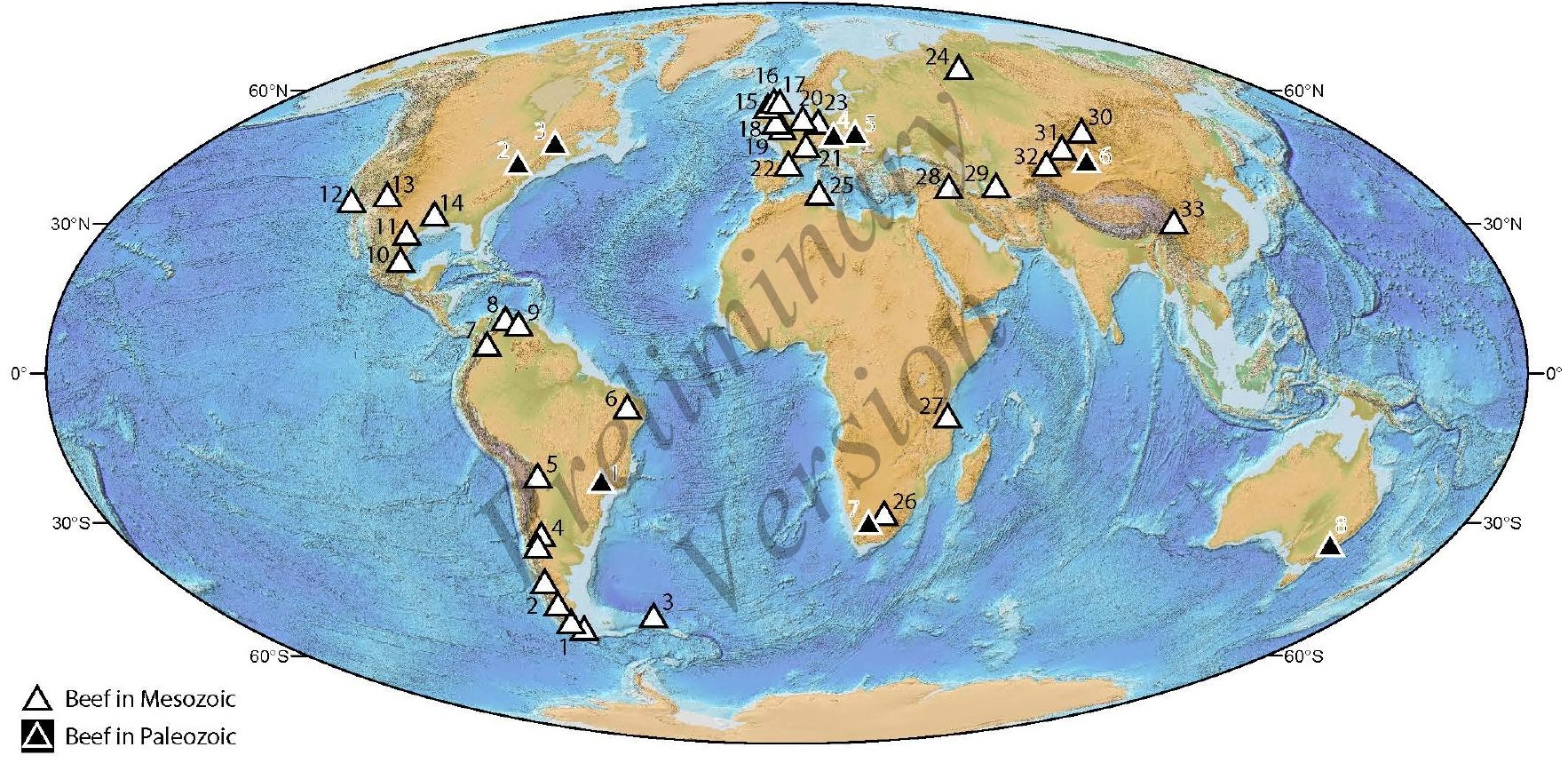



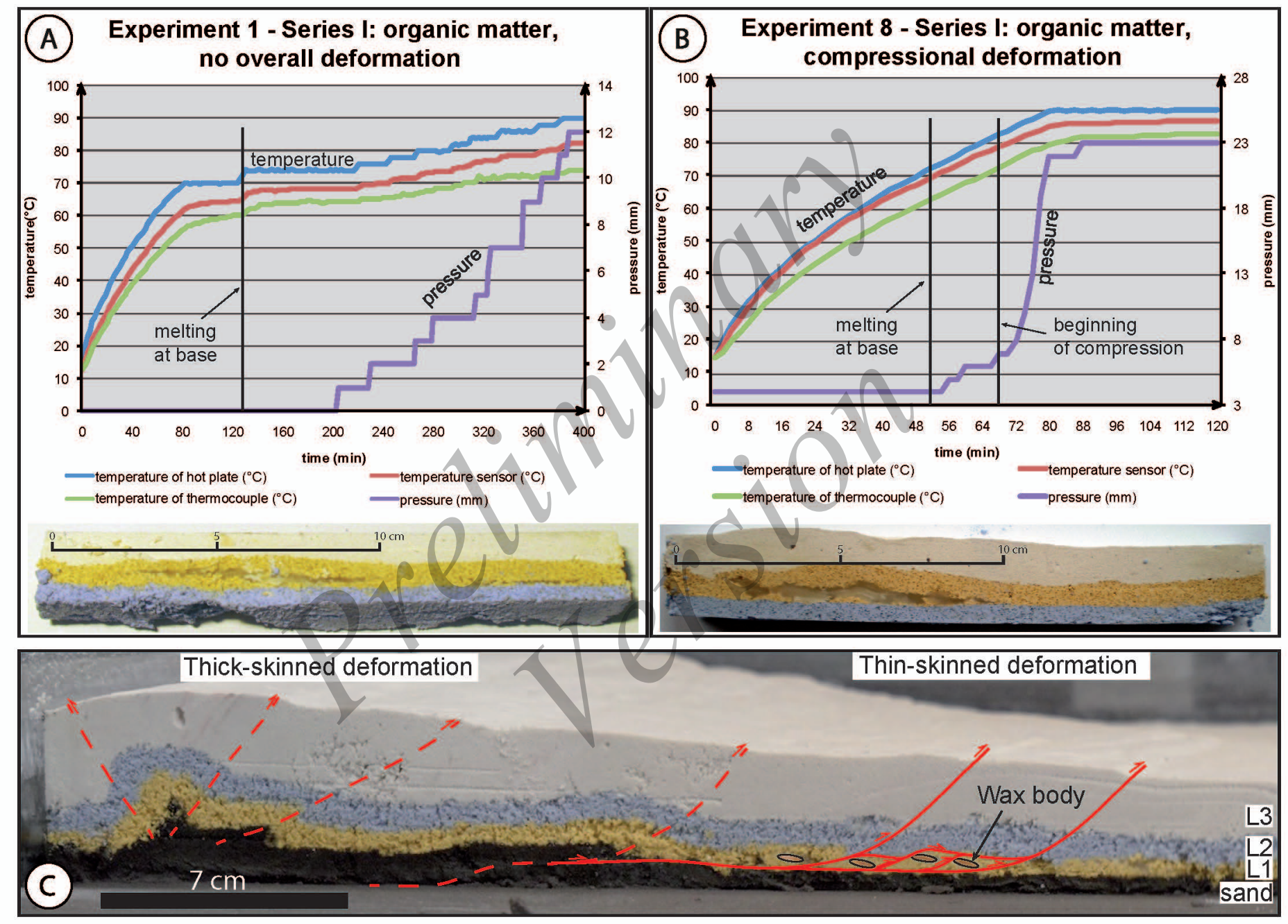
$3^{\circ} \mathrm{W}$

$1^{\circ} \mathrm{W}$
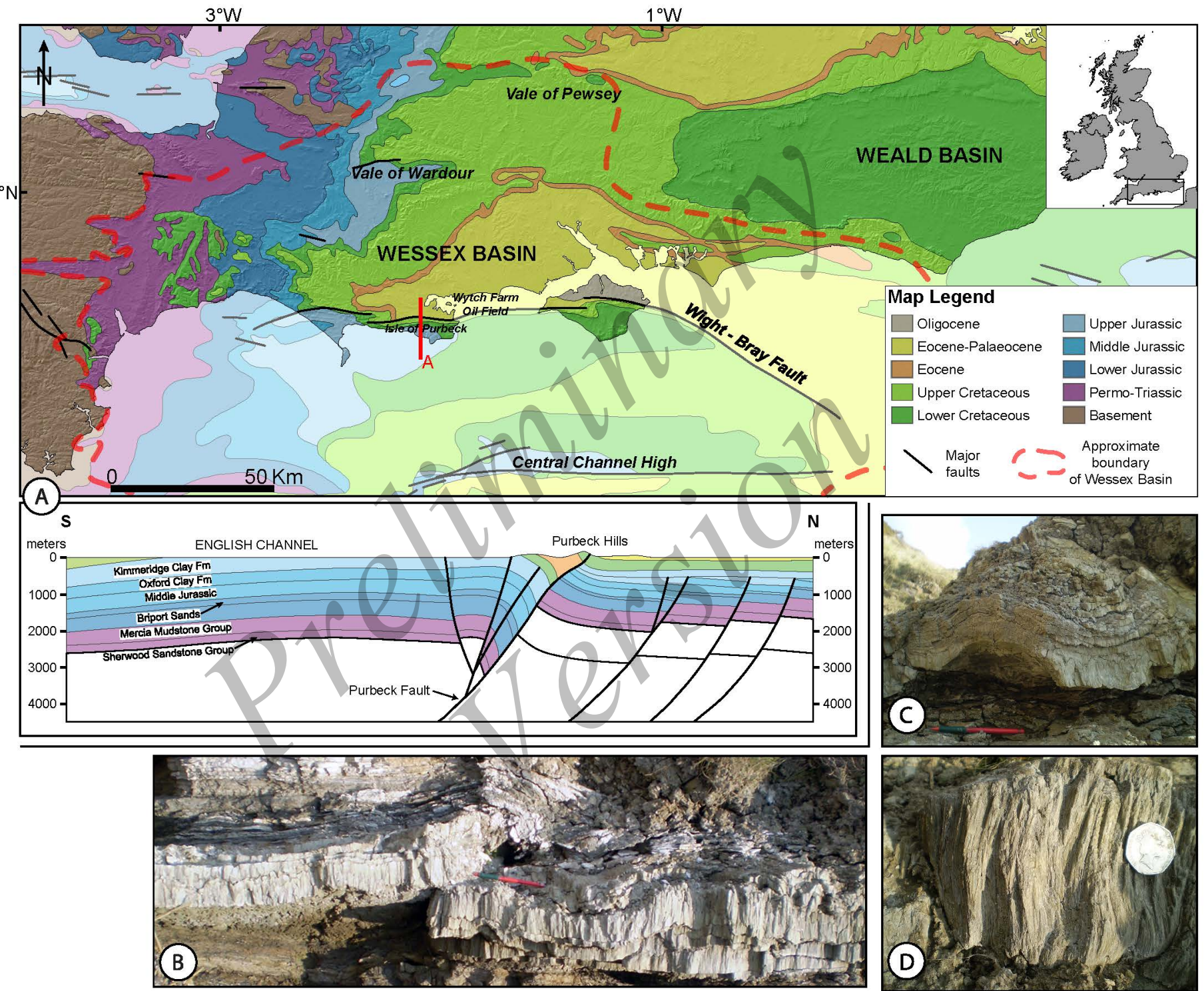
\begin{tabular}{ll}
$70^{\circ} \mathrm{W}$ \\
\hline
\end{tabular}
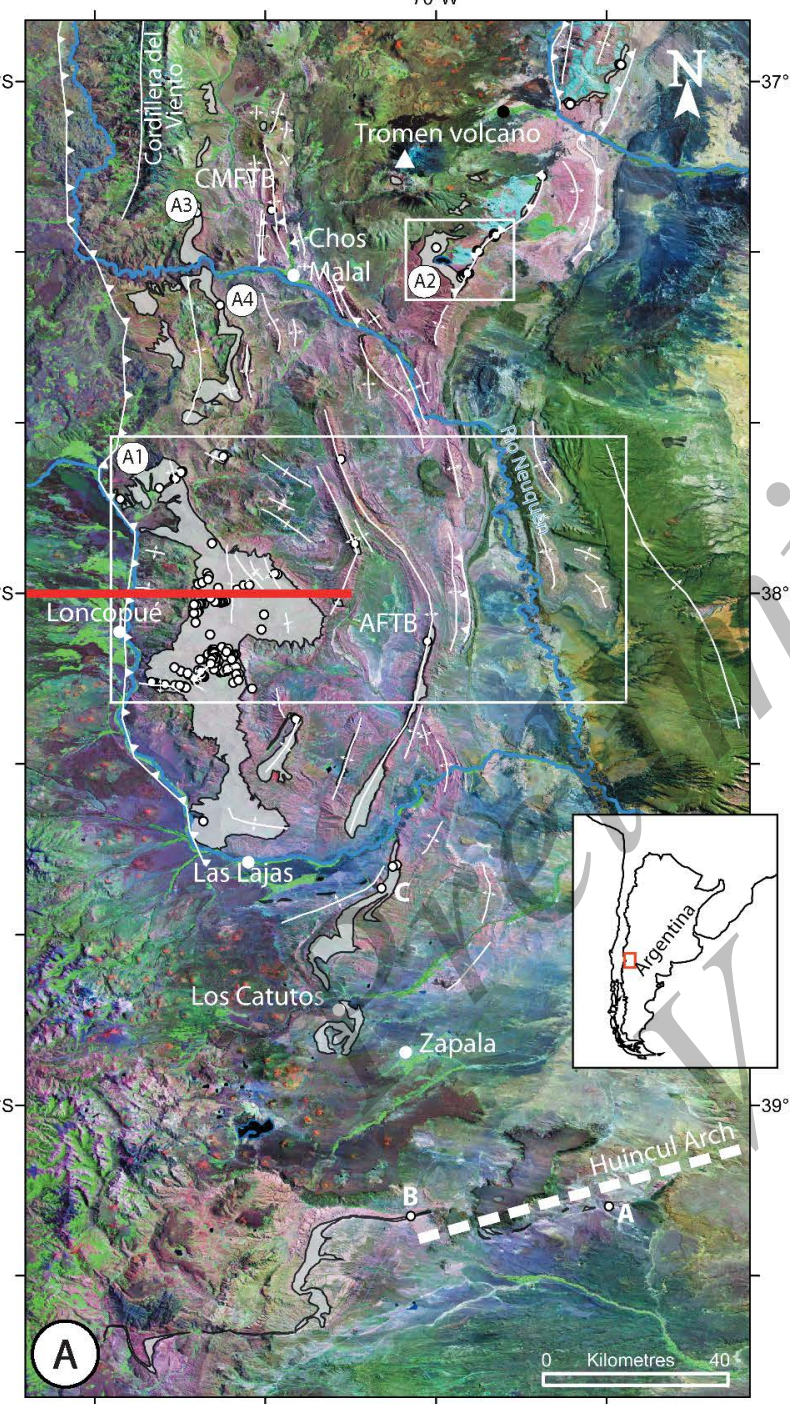

$70^{\circ} \mathrm{W}$

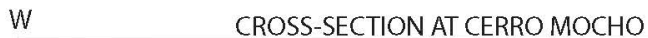

E
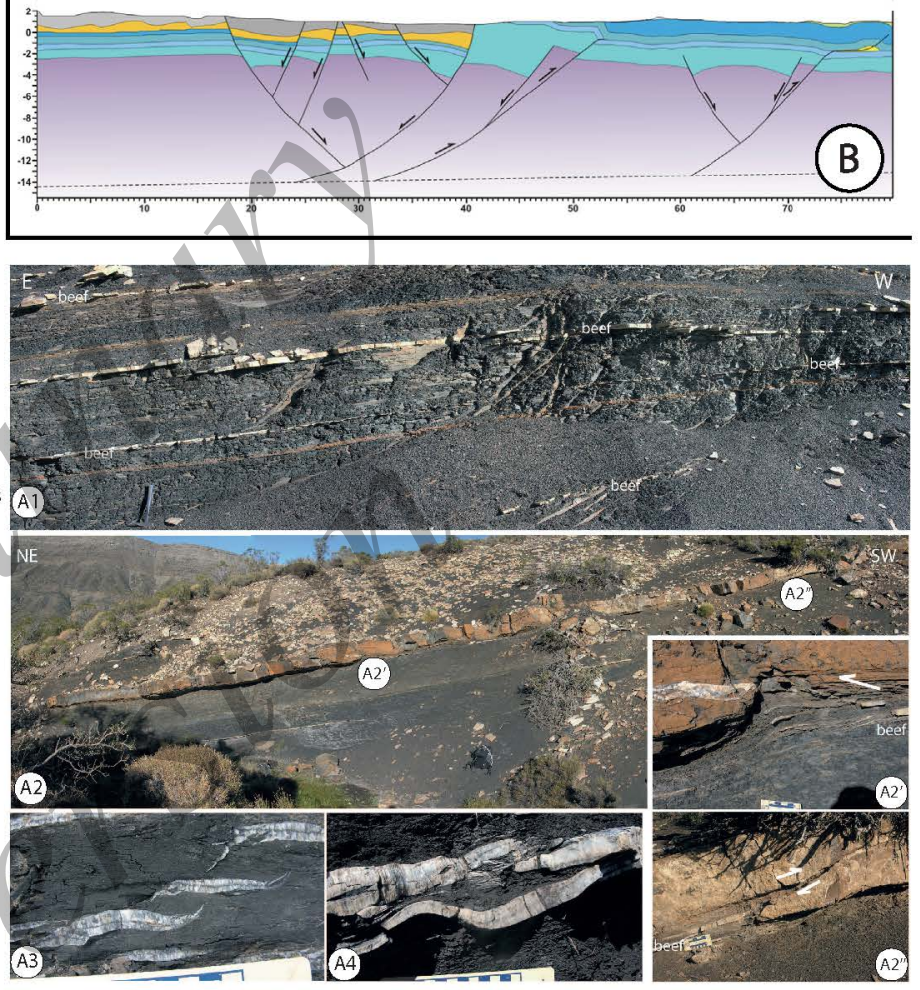

$\square$ Areas of outcropping Vaca Muerta Fm

- Studied localities within Vaca Muerta Fm

- River

- Anticline

Thrust fault

- Strike-slip fault

AFTB Agrio fold-and-thrust belt

-MFTB Chos-Malal fold-and-thrust belt 


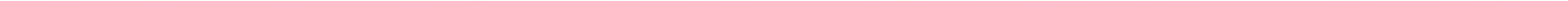




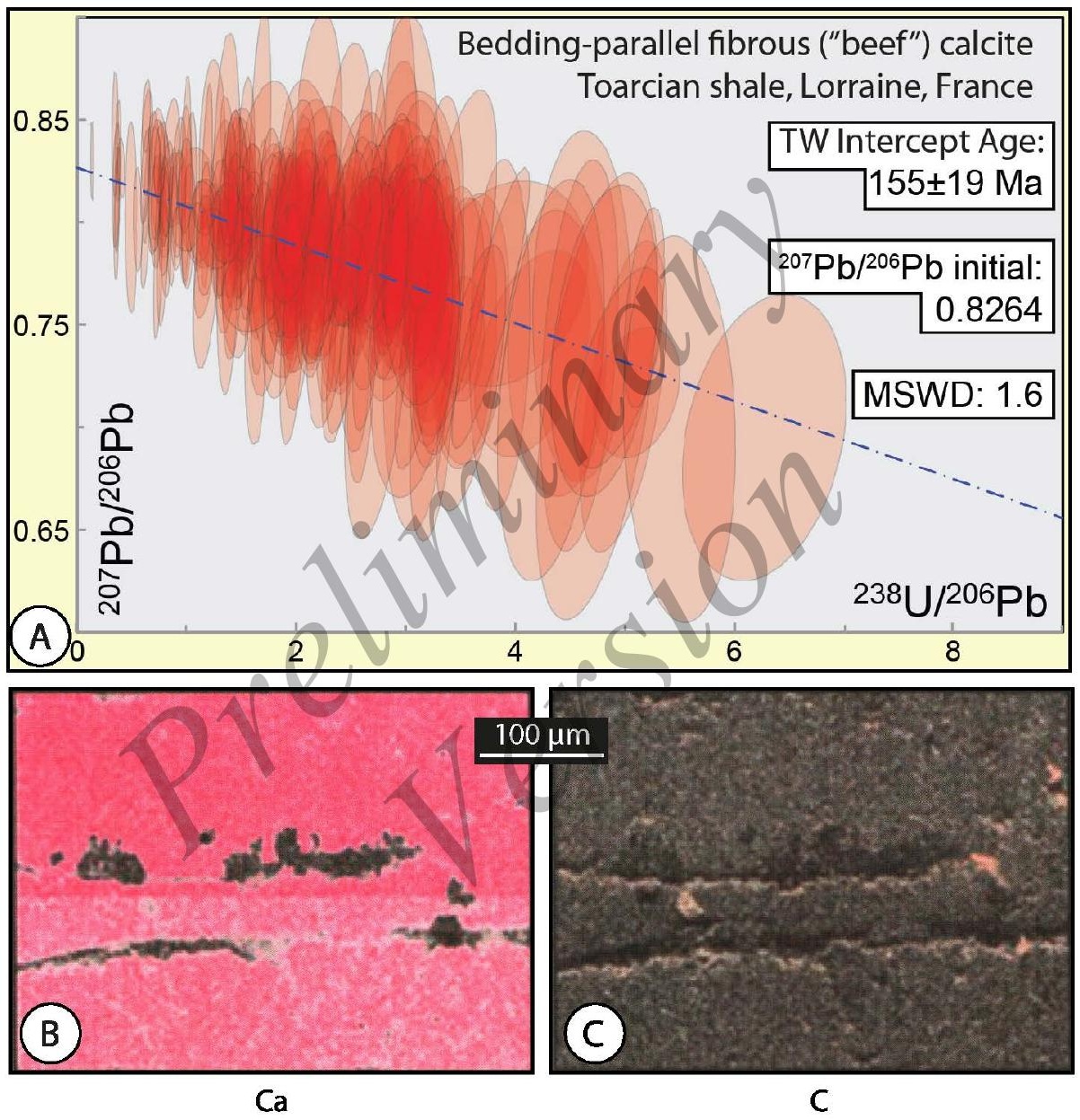




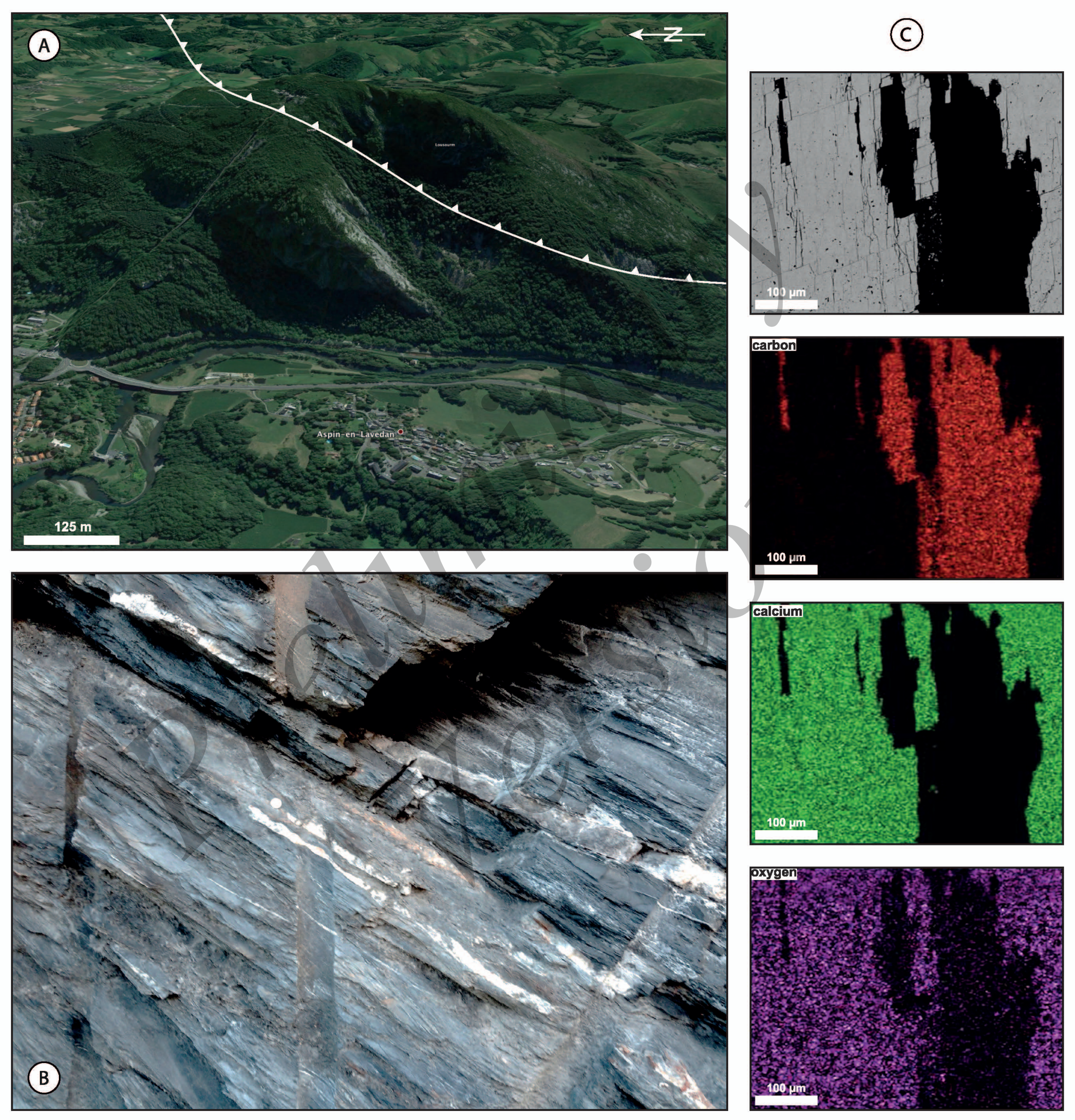



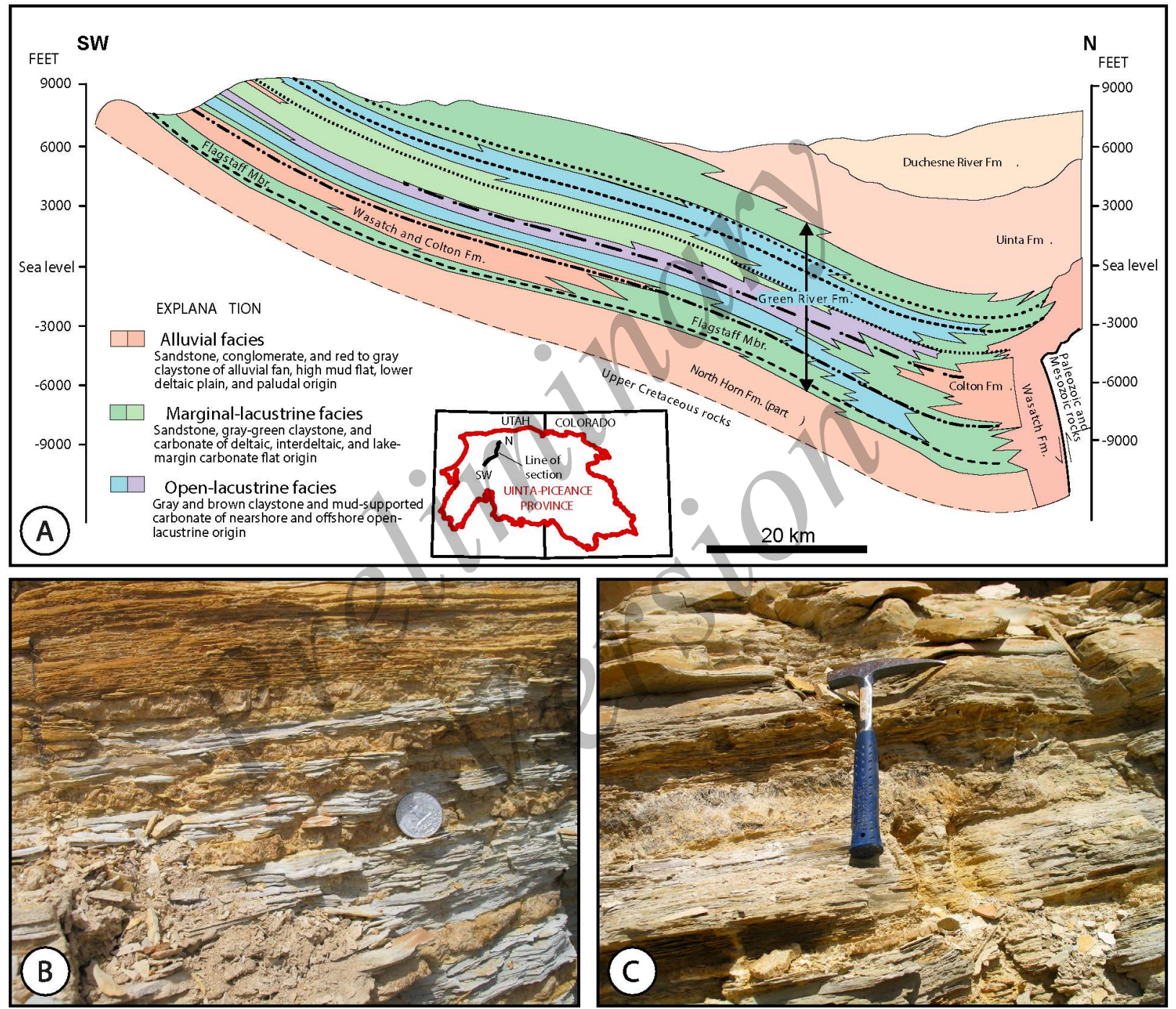

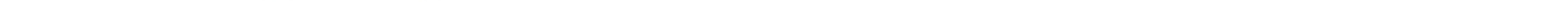

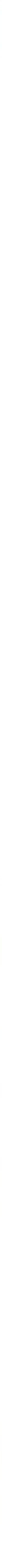
4 Neuquén Basin, Argentina, Los Molles, Vaca Muerta, Agrio Fms (Jurassic to Cretaceous) Fig. 4; Rodrigues et al., 2009; Cobbold et al., 2013; Gale et al., 2014; Ukar

5 Sub-Andean Zone, southern Bolivia (Tertiary strata)

6 Araripe Basin, NE Brazil (Early Cretaceous)

7 Eastern Cordillera, Colombia, (Early Cretaceous source rock)

8 Northern Venezuela, La Luna Fm (Late Cretaceous)

9 Northern Venezuela, Oficina Fm (Early Miocene)

10 Central Mexico Fold-and-Thrust Belt, (Cretaceous)

11 Sierra Madre Oriental, NE Mexico (Jurassic-Cretaceous)

12 SW California, USA, Franciscan Complex (Late Jurassic to Cretaceous)

13 Uinta Basin, Utah, Green River Fm (Eocene)

14 Texas, Haynesville Shale (Jurassic)

15 Outer Hebrides (Eigg, Raasay, Skye), Scotland, UK (Jurassic)

16 Eathie, Great Glen, NE Scotland (Jurassic)

17 Alba Field, Outer Moray Firth, UnitedKingdom (Eocene)

18 Lavernock Point, South Wales (Triassic)

19 Wessex Basin, UK (Liassic to Mid-Cretaceous)

20 Dutch Central Graben (Toarcian)

21 Eastern and Northern Paris Basin, France(Triassic, Liassic)

22 Lourdes, North-Central Pyrenees, France (Aptian-Albian)

23 Hils Syncline, NW Germany (Toarcian)

24 West Siberia Basin, Russia, Bazhenov Shale (Tithonian-Berriasian)

25 Algeria-Tunisia (Cretaceous)

26 Kalahari Desert, South Africa and Botswana (Quaternary)

27 Kilwa, coastal Tanzania (Cretaceous, Paleogene)

28 Tawke Field, Kurdistan, NW Iraq, Sargelu Fm (Jurassic)

29 Kopet-Dagh Basin, NE Iran, Sanganeh Fm (Late Cretaceous)

30 Junggar Basin, China, Xishanyao Fm. (Middle Jurassic)

31 Yili Basin, China, Totounhe Fm. (Middle Jurassic)

32 Issyk-Kul Basin, Kyrgyzstan (Jurassic)

33 Sichuan Basin, China, Jialingjiang Fm (Triassic) et al. 2017; Zanella et al., 2015

Labaume et al., 2001; Lamb, 2004

Silva, 2003; Marques et al., 2014

Fig. 5; Cobbold et al., 2013; Mora et al., 2013; Mora et al., 2015

Macsotay et al., 2003

Martinius et al., 2012

Fitz-Diaz et al., 2011

Fischer et al., 2009; Smith et al., 2014

Bradbury et al., 2015

Fig. 9; Woodland, 1964; Dubiel, 2003

Gale et al., 2014

Lee, 1920; Marshall, 1982; Parnell et al., 2014

Le Breton et al., 2013

Hillier \& Cosgrove, 2002

Kershaw \& Guo, 2016

Fig. 3; Buckland \& De la Beche, 1835; Richardson, 1923; Marshall, 1982

Underhill \& Stoneley, 1998; Cobbold \& Rodrigues, 2007; Zanella et al.,

2015b; Kershaw \& Guo, 2016

Trabucho-Alexandre et al., 2012

Figs. 6 \& 7; Denaeyer, 1943, 1947; Voisin, 1999; Cobbold et al., 2015

Fig. 8; Choukroune, 1969; Biteau \& Canérot, 2007

Leythaeuser et al., 1988

Kemp, 2014; Fjellanger et al., 2015

David, 1952

Watts, 1978

Pearson et al., 2006

Lilloe-Olsen \& Bang, 2012

Mahboubi et al., 2010

Fig. 10; Jolivet et al., 2010; Heilbronn, 2014

Fig. 10

Fig. 10

Zhang et al., 2015 


\section{B. Palaeozoic or Precambrian host rocks}

1 Parana Basin, SE Brazil, Teresina Fm (Permian)

2 Appalachian Mountains, USA, MarcellusFm (Devonian)

3 Appalachian Mountains, Quebec, Canada, Utica Shale Fm (Ordovician)

4 Barrandian Basin, Czech Republic (Lower Palaeozoic)

5 Holy Cross Mountains, Poland (Devonian, Triassic)

6 Junggar Basin, China, Lucaogou Fm (Upper Permian)

7 Kalahari Desert, South Africa and Botswana, (Silurian-Devonian)

8 Australia, New South Wales, Murrumbidgee Fm (Devonian)

Nomura et al., 2014

Fig. 11; Gilman \& Metzger, 1967; Evans, 1995; Tobin et al., 1996; Gale et

al., 2014; Aydin \& Engelder, 2014

Séjourné et al., 2005; Chatellier, 2013

Suchy et al., 2002; Volk et al., 2002

Kowal-Linka, 2010; Rybak-Ostrowska et al., 2014

Jiao et al., 2007

Watts, 1978

Barker et al., 2006

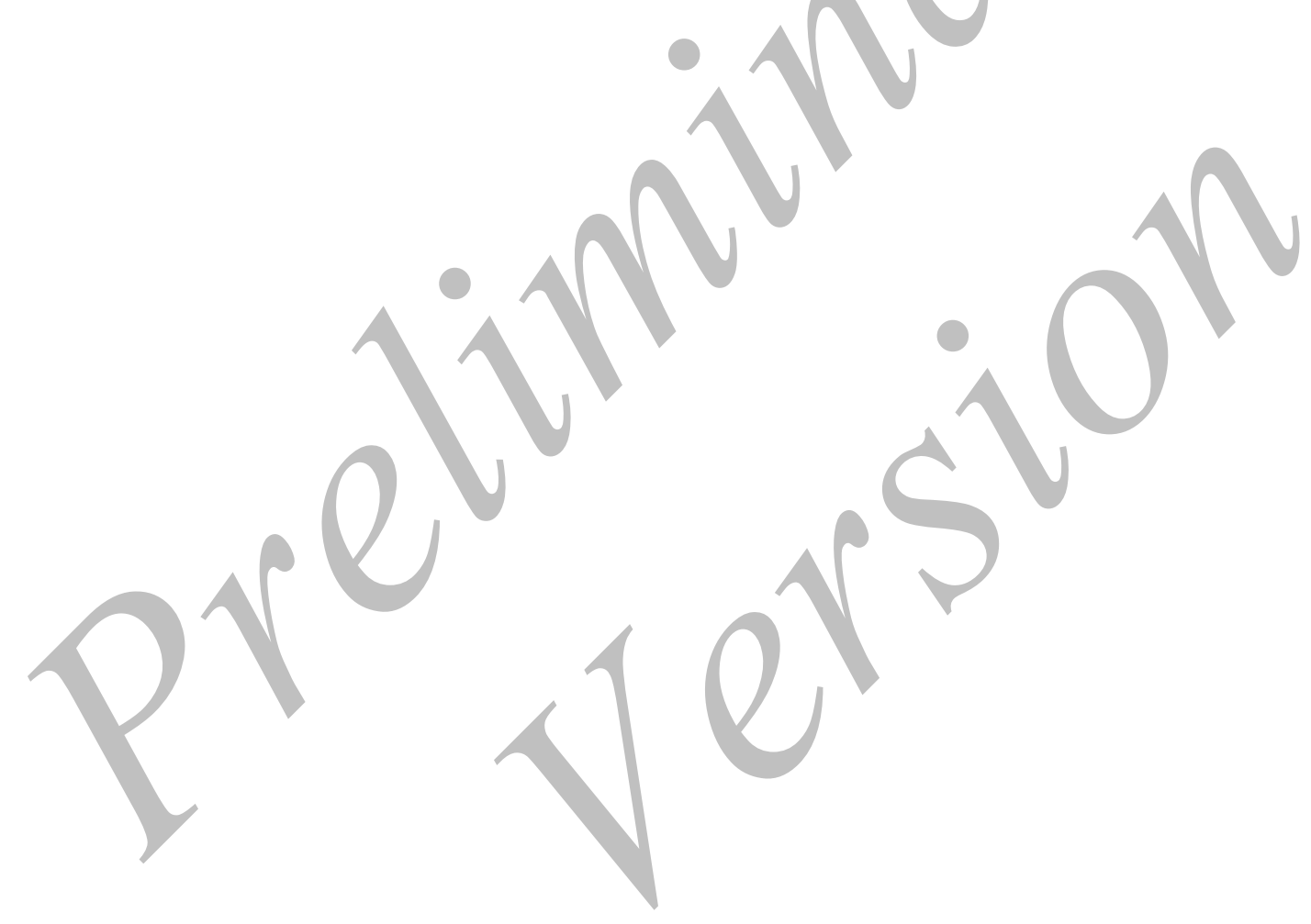

